\title{
Alegoría agraria y futuros globales ${ }^{1}$
}

\author{
Anna Lowenhaupt Tsing \\ University of California Santa Cruz, Anthropology Department \\ atsing@ucsc.edu
}

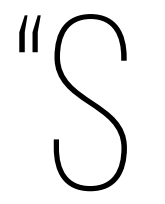

olo dos fuerzas son esencialmente nacionales y portadoras del futuro: el proletariado y los campesinos”, escribió a principios del siglo pasado el teórico político Antonio Gramsci (1968, 51). En el siglo XX, los obreros y campesinos se constituyeron en las categorías básicas para pensar la política. Sin embargo, en el siglo XXI ambas han desaparecido de la discusión pública; no se mencionan pero orientan por doquier tanto la política pública como la investigación académica. Los tropos a través de los cuales las conocemos han calado como "hechos" bien conocidos sobre la vida social urbana y rural. Aparecen en la forma de estadísticas, anécdotas y lugares comunes, y son explicados como "realidades sociales". Sin embargo, estas realidades están moldeadas por las preguntas que hacemos y por las maneras en que narramos la historia. Los campesinos y los obreros son figuras alegóricas cuyas historias todavía nos acompañan. Este ensayo examina las alegorías que dan forma al campesino. Para hacer más claras las historias del campesinado, las comparo con la recientemente renovada alegoría de la tribu.

A lo largo del sur global, dos tipos de alegorías rurales moldean las políticas administrativas, los programas académicos y las agendas de los activistas, así como las metas y planes de las poblaciones rurales con las cuales esos administradores, académicos y activistas trabajan: las campesinas y las tribales. Las apreciaciones internacionales sobre la conservación, el desarrollo y la equidad nos transportan una y otra vez a escenas rurales imaginadas de campesinos o de tribus. Uso los conceptos campesino y tribu sin mucha rigidez para referirme a cómo se ha pensado tradicionalmente el sur rural, ya sea un lugar de agricultores a menudo pobres, en desventaja y rebeldes ("campesinos") o de comunidades culturalmente ricas y políticamente diferenciadas (“tribus”).

1 Traducción de "Agrarian Allegory and Global Futures", publicado en Nature in the Global South. Environmental Projects in South and Southeast Asia, editado por Paul Greenough y Anna Lowenhaupt Tsing, 124-169. Durham: Duke University Press. El Instituto Colombiano de Antropología e Historia agradece a Anna Tsing y a Duke University Press por haber otorgado los derechos de traducción y reimpresión de este manuscrito. 
En este ensayo mi tema de interés no son los términos o las personas que estos describen, sino las imágenes, narrativas, supuestos, marcos de referencia y convenciones que se usan para conocer, ayudar o gobernar, y que han hecho tan poderosas internacionalmente a estas escenas rurales imaginadas. En círculos ambientalistas, las tribus han orientado planes para conectar la preservación de la diversidad biológica y cultural, mientras que a los campesinos se los ha invocado para tener en cuenta la equidad medioambiental. La divergencia entre las agendas tribales y campesinas es a menudo amplia y los programas medioambientales mencionados con frecuencia se encuentran profundamente enfrentados; cada cual rechaza la agenda del otro por considerarla ajena a su propio imaginario de lo que es una buena política. No obstante, estas agendas pueden estar dirigidas a las mismas personas.

Consideremos a Rintas e Isan, dos hombres que conozco y que viven en las montañas Meratus en el sur de Kalimantan Meridional, Indonesia ${ }^{2}$. Ambos son líderes elocuentes y ambiciosos, reconocidos en sus respectivas comunidades de agricultores itinerantes y recolectores de la selva húmeda, pero con distintos sueños de liderazgo y de futuro global.

Desde que se convirtió en jefe de la aldea, Rintas ha estado ocupado construyendo cercas y registrando las tierras de cultivo. Antes de que fuera jefe, nadie tenía cercas o reclamos de tierra reconocidos por el Estado. Él quiere cambiar esta situación y espera convertir a los pobladores en ciudadanos rurales ante los ojos del Gobierno. Con el fin de lograr este objetivo, está dispuesto a domesticar las ceremonias de la aldea, sedentarizar los planes de vivienda tradicionalmente itinerantes, así como acatar las disposiciones nacionales de desarrollo que estipulan las costumbres rurales adecuadas, incluida la diferencia entre el predio de cultivo que se reclama en posesión y el bosque sin reclamar. Él tiene un sueño, tal vez una fantasía, pero no por ello menos realizable.

Este sueño también ha tenido influencia en la aldea de Isan, donde un conjunto de residencias permanentes son testimonio de los estándares que tiene el Gobierno para la vida rural. No obstante, Isan está siguiendo una ruta diferente; como anciano de la aldea, trabaja con un grupo ambientalista para reclamar el bosque, promover el ecoturismo y proteger los derechos de la aldea de manejar los recursos al modo “indígena”. Él también tiene una meta y, para alcanzarla, está dispuesto a “exotizar” las ceremonias de la aldea, mostrar y presumir del

Estos nombres son seudónimos. El breve recuento sobre el trabajo de estos dos hombres
deriva de mi trabajo de campo en 1994. Para profundizar sobre el pueblo dayak de las montañas Meratus, ver Tsing (1993). 
conocimiento de la selva, mapear los reclamos de la aldea sobre el bosque y revivir las costumbres que puedan considerarse locales.

De una manera sintética, uno podría llamar al sueño de Rintas una fantasía campesina con predios de cultivo estables, leyes e impuestos, y al sueño de Isan, una fantasía tribal con bosques manejados a partir del conocimiento indígena. Ninguno de los dos sueños es estrictamente local, puesto que ambos implican involucrarse con poderosos forasteros y con ideas que han circulado de diversas maneras alrededor del mundo. Ninguno de estos sueños se basa en una descripción neutral u objetiva de la aldea en las montañas Meratus, y ambos requieren reimaginar y reconstruir la aldea para darle vida al sueño. Los dos sueños demuestran la importancia que cobra la "alegoría agraria” en la configuración de las situaciones e historias contemporáneas.

Algunas de las estrategias más prometedoras de la política ambiental del "sur" implican mezclar estas dos narrativas. Los movimientos ambientalistas del Asia Suroriental usan alegorías tribales y campesinas de una manera creativa y ecléctica para impulsar sus movilizaciones. En Indonesia, Malasia y Filipinas, una de las características más apasionantes de los sectores de los movimientos ambientalistas orientados a la justicia social es su interés por las personas que nunca antes habían sido incluidas en populismos nacionales; personas que fueron consideradas demasiado marginales, demasiado diferentes culturalmente o demasiado desinformadas sobre los estándares políticos nacionales. Estas son las tribus alegóricas: gente de las tierras altas, gente de la selva húmeda, no cristianos en Filipinas y no musulmanes en Malasia, que en las discusiones de estos movimientos ambientalistas se mezclan con las poblaciones rurales pobres que por mucho tiempo han estado en el centro del debate nacional, es decir, los campesinos. Mientras que el populismo en Indonesia en un momento dado abordó solo a los javaneses, los ambientalistas han incluido al pueblo dayak de Kalimantan y a los papúes de Irian. El movimiento ambientalista malasio tiene en cuenta los dilemas de los nómadas penan, así como de los agricultores malayos. El movimiento ambientalista filipino ha incluido a los bukidnones y maguindanaos de las tierras altas en las discusiones políticas nacionales que alguna vez habían involucrado principalmente a los agricultores arrendatarios de Luzón Central. Estas inclusiones crean una diferencia en comparación con los movimientos progresistas y nacionalistas anteriores, que se enfocaron en una historia “campesina” mucho más estrecha sobre la población rural ${ }^{3}$.

3 Para una introducción útil sobre el ambientalismo indonesio, ver Mayer (1996). Para las alianzas ambientales en Filipinas, ver Broad y Cavanagh (1993). Para algunas de las preocupaciones de los ambientalistas malasios, ver Sahabat Alam Malaysia (1987). 
La atención nacional no resuelve los problemas de la jerarquía urbanarural ni significa que los organizadores urbanos entiendan a cabalidad los problemas rurales (Baviskar 2003). No obstante, este es un desarrollo importante y un buen augurio para las nuevas discusiones acerca de la democracia nacional que estos movimientos están intentando generar. Al mezclar y combinar las narrativas tribales y campesinas, aquellos que se identifican como tribus y como campesinos se encuentran incluidos en la misma publicidad, y las alegorías se influyen de manera constructiva. Así, las tribus son consideradas en las preocupaciones populistas de los campesinos por los derechos a la tierra y la justicia social y, por su parte, los campesinos se benefician de los reclamos tribales acerca del conocimiento indígena y el manejo forestal según sus usos y costumbres. Al yuxtaponer la retórica asociada con las tribus por un lado y con los campesinos por el otro, se crea una nueva apertura política para el diálogo nacional sobre las condiciones en el campo.

Los investigadores académicos no se han enfocado mucho en la confusión creativa de las narrativas tribales y campesinas. En vez de observar las formas en que las narrativas moldean las instituciones, los paisajes y las vidas, se han estancado tratando de separar las historias verdaderas de las falsas. Al atender a sus discursos, uno queda con la impresión de que las historias tribales son fantasías insinceras mientras que la condición del campesinado es real. Aunque puedo entender por qué se desarrolló esta división, esto no ayuda, pues lleva a un callejón sin salida tanto político como intelectual. ¿Cómo llegaron los investigadores a esto? Dos agendas progresistas se han chocado. Los antropólogos culturales y los críticos literarios poscoloniales critican las ideas sobre la diferencia cultural tribal como una falsa exotización ${ }^{4}$. Los investigadores de los estudios campesinos desmitifican las ideologías elitistas al develar la verdad del pueblo ${ }^{5}$. Entonces, a primera vista las tribus son falsas y los campesinos, verdaderos. Sin embargo, dividir a los narradores entre falsos y verdaderos suprime de nuestra consideración las preguntas sobre la representación, el significado y la narrativa. Un mejor marco de referencia pone en pie de igualdad a las tribus y a los campesinos, como categorías que han moldeado no solo la academia sino también

4 Aquí las referencias estándar son Said (1978) y Clifford y Marcus (1986). Los académicos críticos de la exotización cultural en los movimientos ambientalistas de Asia Suroriental incluyen a Brosius (2003), Li (2000) y Zerner (1994). Mi intento de presentar un análisis de los beneficios locales de la narrativa tribalista puede encontrarse en Tsing (1999). 
las políticas administrativas que producen el paisaje, las estrategias políticas y económicas, así como la vida rural.

Para abordar el papel formativo de la alegoría en la orientación de proyectos ambientales desde lo global hasta lo local, se requiere que pongamos atención a historias específicas. En este ensayo trazo la formación de la figura del campesino en Indonesia, Malasia y Filipinas. Las historias tribales serán de mi interés principalmente como un recordatorio de la especificidad y los límites de las historias sobre el campesinado. En particular, examino la construcción de una imagen del paisaje rural como lugar de pobreza, identidad nacional y lucha de clases. En la figura del agricultor o del obrero sin tierra situado en este paisaje, los académicos han encontrado un narrador de verdades importantes, verdades que retan el dogma político-económico dominante a nivel internacional al mostrar el lado oculto de la jerarquía, la explotación, la militarización, la gobernanza estatal, la experticia técnica y la expansión del capital. Los reclamos cargados ideológicamente acerca de la homogeneización global hacen todavía más importante este conocimiento subalterno para cualquiera que se preocupe por el mundo de hoy $^{6}$. Sin embargo, gana su capacidad de contar verdades importantes políticamente a partir de una historia que "campesiniza" el paisaje, es decir, lo moldea en relación con las alegorías campesinas. La figura del campesino adquiere su carga política dentro de la institucionalización de un conjunto de compromisos para la construcción del paisaje que van desde proyectos administrativos coloniales hasta rediseños nacionalistas y desarrollistas de los pobladores rurales.

La construcción alegórica del campesinado es una cuestión importante alrededor del mundo, pero Asia Suroriental es un lugar particularmente valioso para empezar una discusión. Primero, aunque Asia Suroriental ha sido a menudo descrita en los términos clásicos de las narrativas campesinas, los motivos tribales también son sobresalientes, de manera que esta combinación hace que el tema campesino cobre relevancia, a la vez que muestra sus límites. Por el contrario, las historias campesinas en Asia Oriental dominan de tal manera la comprensión del campo, que solo se puede imaginar la historia como una de campesinos y élites. Otro contraste sería África, donde la idea de la tribu ha predominado. Dado el resentimiento de muchos africanos educados con respecto al concepto de tribu, no puedo imaginar un papel positivo para las alegorías tribales en el ambientalismo africano. Esta clase de connotación peyorativa es menos

6 Ciertos académicos han argumentado que los campesinos son una forma social arcaica de poca relevancia para el mundo de hoy (p. ej., Kearney 1996). En cambio, yo encuentro trazos de alegorías campesinas en todas partes, aun cuando problematizo la retórica naturalista mediante la cual los académicos relatan su existencia previa. 
hegemónica en Asia Suroriental, donde las historias tribales les ofrecen a los pobladores, además del estigma del atraso, posibilidades de autonomía cultural. Por ejemplo, en los años ochenta en las tierras altas de Filipinas, los líderes exigieron que se llamara "tribus” a su gente y no "minorías”. En Asia Suroriental, las alegorías tanto tribales como campesinas son recursos disponibles para las movilizaciones ambientalistas.

En segundo lugar, la diferencia que divide a aquellos que se imaginan como tribales y a aquellos que se imaginan como campesinos nunca ha sido institucionalmente estable y, en la medida en que estas categorías cambian, sus características alegóricas emergen más claramente. El Asia Suroriental nunca experimentó las olas masivas de inmigración europea y africana que crearon en Latinoamérica una categoría especial de pueblos indígenas imaginados como tribus diferenciadas racial, cultural y lingüísticamente, y que presentaba contrastes en términos de civilización con respecto a los colonos blancos, los exesclavos y los agricultores “sedentarizados”, imaginados como campesinos. En Asia Suroriental, y a diferencia de la India, la categoría tribal no es una identidad jurídica separada de la mayoría organizada según castas y adherida a las personas incluso fuera de su entorno nativo. Por el contrario, la división entre lo tribal y lo campesino está orientada hacia la organización de los paisajes y las comunidades. Todo estudiante de la región empieza por aprender las distinciones entre las tierras altas y bajas de Filipinas, el oriente y occidente de Malasia, y el interior (las islas de Java, Madura y Bali) y el exterior (las demás islas) de Indonesia, divisiones empíricas generales que guían las descripciones del campo en las historias tribales versus las campesinas. La fragilidad histórica de estas distinciones llama la atención sobre el papel formativo de la alegoría agraria en el diseño de los paisajes y las comunidades en Asia Suroriental.

Sin embargo, y en tercer lugar, Asia Suroriental está lejos de ser un lugar homogéneo: muchos de los argumentos académicos para considerarla una región en cualquier sentido tienen que ver con la atención que se ha prestado a su diversidad. Teniendo en cuenta que el paisaje de Indonesia, Malasia y Filipinas es un área demasiado grande y a la vez demasiado pequeña para considerarse, mi objetivo no es presentar una historia definitiva sino abrir puertas a nuevas maneras de pensar. Más aún, esta región ha sido privilegiada por la elaboración de un número de descripciones “clásicas”, tanto etnográficas como históricas, de la vida rural, cada una de las cuales ha abierto caminos teóricos que han influido en el desarrollo de las ciencias sociales. En cada sección de mi exposición, analizo una de ellas para ilustrar la promesa y el reto de repensar las narrativas campesinas. 
Este ensayo explora el desarrollo de la figura alegórica del campesino como una fuente de verdades políticamente desafiantes. Estas verdades no son solamente aquellas enunciadas por los campesinos sino también aquellas aprendidas por los investigadores, los defensores y los formuladores de políticas públicas a través de su contacto con campesinos. Arguyo que esta habilidad para contar verdades surge de una historia específica de politización y de construcción de paisaje en el Asia Suroriental insular. Las élites indígenas desarrollaron ideales diferenciados, relativos a los paisajes productivos y a las comunidades leales, centrados en el cultivo de arroz en terrenos inundados. Los administradores coloniales fueron influenciados por estos ideales, que rediseñaron y extendieron para ajustarlos a sus nociones sobre las poblaciones rurales administrables. A su vez, los grupos y lugares de los “campesinos modelo" se volvieron ejemplos paradigmáticos de la campesinidad en el imaginario que predominaba entre los europeos que interactuaban con ellos y ejercían el control colonial. Este modelo de campesinidad se reprodujo en nuevos sitios, mientras que otros tipos de comunidades y paisajes rurales fueron marginalizados, criminalizados o rediseñados, por cuanto la Administración política se centró en los campesinos modelo y sus paisajes.

Las nuevas naciones que emergieron de estos territorios coloniales no dejaron de privilegiar políticamente a los paisajes y comunidades de campesinos modelo, y con la independencia nacional, estos grupos se convirtieron en los representantes de la ruralidad de la nación. Al cumplir este papel, tales paisajes y grupos de campesinos modelo también llegaron a ser los principales objetivos de las intervenciones desarrollistas, de las movilizaciones políticas y de las alertas de seguridad internas. Sin embargo, durante el proceso, su construcción como campesinos modelo se olvidó y, en vez de campesinos, llegaron a ser descritos como masas, desde el punto de vista económico, político y demográfico, y se convirtieron en la fuente alegórica del hombre común y corriente de la nación.

Los estudios campesinos intervinieron en esta descripción social carente de forma, para señalar las características estructurales de la vida campesina prototípica, aun en el contexto del nacionalismo y del desarrollo, e hicieron que de repente la estratificación volviera a ser clara. Como campesinos, estos pobres hombres comunes y corrientes del campo tenían algo nuevo que decir, a menudo algo agudamente crítico sobre la indiferencia de las visiones elitistas. Pero los estudios campesinos heredaron dicha naturalización de los campesinos modelo como hombres comunes y corrientes de la nación, y así con frecuencia se olvidaron de la particularidad de la construcción social de estos críticos políticos subalternos. Al argüir a favor de una nueva atención crítica a la historia de la narrativa 
campesina, tanto en la investigación académica como en la administración, espero abrir un espacio para otras narrativas más flexibles, que puedan incluir una variedad de personas y de historias rurales más amplia. En un momento en que tanto ecologistas políticos y sociales, como otros tipos de teóricos del ambiente y la justicia social, recurren acertadamente a la herencia de los estudios campesinos para pensar y analizar los dilemas agrarios, necesitamos usar este patrimonio de la manera más enriquecedora posible ${ }^{7}$. Con esta guía a la mano, invito al lector a una gira por un terreno histórico regional demasiado extenso para que cualquier académico lo conozca con el merecido detalle. Los documentos sobre los campesinos modelo son enormes y abrumadores, y mi punto de observación no es enciclopédico sino el de una académica de las personas “marginales”, aquellas que han sido dejadas por fuera de estas investigaciones. Espero que mis errores sean fuente para una conversación continua sobre estos asuntos.

Cuando los europeos viajaron por primera vez al Asia Suroriental, encontraron una variedad de formas sociales entrelazadas: reinos en el interior sostenidos por el arroz irrigado; reinos costeros que gravaban a las rutas de comercio; "piratas” y comerciantes de alta mar; aldeas costeras de tierras bajas y de tierras altas; cultivadores itinerantes en parcelas aisladas; recolectores ambulantes de productos de mar y de bosque, y más. De todos estos, los europeos solamente reconocieron a los reinos como actores políticos y por ende comerciaron, batallaron y expropiaron

La literatura académica ambientalista se ha nutrido en gran medida - consciente e inconscientemente- de estas alegorías agrarias. Por ejemplo, las alegorías campesinas y tribales sobre los bosques son notablemente distintas, y su divergencia subraya la importancia de prestar atención a estas historias formativas. Ambas se oponen al estereotipo desarrollista dominante que sostiene que la gente del campo necesariamente destruye los bosques. No obstante, cada una desafía este credo de una manera diferente. La historia campesina gira alrededor de los términos en que se puede salvar el bosque: ¿por qué la población local no debe oponer resistencia y traspasar los cercados de la élite? La historia tribal cuestiona supuestos sobre el uso local: cuando se le permite operar sin las coerciones del Estado, la población local es conservacionista. En las historias campesinas los bosques son representados como espacios lujosos, protegidos por la realeza para placeres nobles; por el Estado para el manejo científico de la madera; y por las élites urbanas para sus usos estéticos y recreativos. Los campesinos se rebelan contra las leyes que acordonan los bosques para el Estado y las élites (p. ej., Guha 1990; Kartodirdjo 1973; Sahlins 1994; Thompson 1975). De hecho, su rebelión contra el bosque es a menudo representada como constitutiva de la conciencia política del campesinado. Por otro lado, la principal característica de las tribus es su conocimiento cultural del bosque. Las tribus son buenos gerentes del bosque porque lo entienden y les importa. Los amerindios precoloniales quemaban el bosque, no como los campesinos que lo incendiaban para molestar a las autoridades, sino como guardabosques para promover la sucesión de ciertas especies arbóreas (Cronon 1983). Se dice que los pueblos tribales cultivan con el bosque y no en contra de este; a diferencia de los campesinos, quienes restringen la diversidad de la maleza, las tribus promueven la biodiversidad en su forma de manejo (p. ej. Posey 1985). Por supuesto que existen diferencias etnográficas entre los distintos grupos que se conforman en ejemplos clásicos de cada una de estas categorías en la literatura respectiva. El poder de estas historias para moldear el análisis sobre el medio ambiente, el activismo y la política pública se construye a partir de esta especificidad etnográfica, pero también va más allá. 
territorio mediante tratados con ellos. Revisando los archivos, los investigadores han descrito estos reinos como mandalas, Gobiernos galácticos, Estados teatrales y Estados segmentarios para mostrar su especificidady diferencia (Reynolds s. f.). En este tipo de Estados, los productores rurales son participantes periféricos y observadores de los rituales de construcción del Estado; dentro y fuera de los ideales del Estado, ellos respaldan versiones de la "pequeña tradición” de las ideologías de élite (Scott 1977). Y aunque muchos productores rurales estaban inmersos en la fuerza de atracción magnética del poder señorial, había movilidad entre el dominio de un soberano y el otro, así como mucho espacio en la periferia de cada soberanía. Aun cuando se encontraban zonas de cultivo de arroz irrigado - con sus cultivadores asentados y a menudo dependientes-, una mayor parte del paisaje era trabajado por medio del cultivo itinerante, el cual era difícil de controlar y gravar para los gobernantes (Dove 1985). Los bosques eran vastos y la movilidad era algo común, con rutas de viaje y comercio bien desarrolladas.

Cuando los europeos llegaron a transformar los paisajes y las comunidades rurales de Asia Suroriental para que se ajustaran a sus estándares de administración, por necesidad trabajaron con las élites locales así como con otros de menor estatus social de la comunidad, para crear nuevos tipos de economías políticas. El cambio del paisaje y de la comunidad conllevó proyectos híbridos en los que las élites y otros miembros de las comunidades, así como los administradores europeos, tenían sus propios intereses. El régimen colonial permitía la proliferación de diferentes modelos en la medida en que los administradores los introducían en nuevas áreas. Sin embargo, solo algunos de estos proyectos híbridos se convirtieron en modelos duraderos de la Administración colonial rural. Una nueva forma de politización acogió estos paisajes y comunidades rurales, en los cuales los administradores coloniales querían producir condiciones modelo. Es esta reconstrucción colonial de la cultura y la política campesinas que caracteriza lo que yo identifico como el "campesinado modelo" (“core peasantry”). Su producción es la primera parada en mi gira.

\section{Fantasías campesinas 1: lecturas}

Durante algún tiempo y hasta el día de hoy, a los gobernantes de los Estados Federados Malayos y a sus asesores les ha causado gran ansiedad el hecho de que sus sujetos malayos, engañados por ilusiones basadas en su riqueza actual pero transitoria, han ido vendiendo sus tierras, herencias y patrimonios familiares 
a cualquiera que estuviera dispuesto a pagarles en efectivo. Enceguecidos por el resplandor del incentivo ofrecido, embelesados por las visiones evocadas de los placeres leteos, no se dan cuenta de que a cambio de esos placeres ilusorios entregan y sacrifican la felicidad de toda una vida. De este modo, una raza de campesinos-propietarios rurales, otrora felices y prósperos, por la misma naturaleza de su país y la manera de sostenerse a sí mismos, incapaces de serlo en cualquier otro, se dan cuenta demasiado tarde de que se han convertido en vagabundos desamparados en su propio país. Los gobernantes de los Estados Federados Malayos y sus asesores sintieron de manera concluyente que, a menos de que se ejerciera un mejor juicio en su favor, el resultado sería la extinción del campesinado-propietario rural malayo (preámbulo de un proyecto de ley de 1912 sobre la promulgación de las reservas malayas).

A pesar del placer de encontrarse con extraordinarias ficciones coloniales sobre los campesinos, tal como la que acabo de citar, una reinterpretación de fuentes primarias está fuera del alcance de este ensayo. En cambio, mi argumento sobre la construcción de los campesinos de Asia Suroriental se forma a partir de leer al mismo tiempo distintos corpus de interpretación histórica. Primero, me baso en el trabajo de muchos autores que narran incidentes de "tradicionalización”, “feudalización”, “involución”, “reservación” y hasta “campesinización” (ver, p. ej., Geertz 1963; Kahn 1980; Lim 1977; Ong 1987; Stivens 1983) ${ }^{8}$. En varios tiempos y lugares, nos enteramos de que los agricultores de Asia Suroriental han sido objeto de políticas públicas militares, comerciales y administrativas que los atan a determinadas parcelas de tierra, los incentivan a trabajarlas usando mano de obra familiar, les especifican los cultivos y las tecnologías, les restringen la iniciativa empresarial y la movilidad, y, a través de relaciones determinadas, los atan a representantes de las élites. Esta rica y apasionante literatura contradice conscientemente las fuertes suposiciones ideológicas de que la "tradición" campesina es el punto de partida inicial que se está disolviendo para dar paso a lo nuevo y "moderno”. La literatura muestra que las políticas públicas y los programas económicos estatales pueden influenciar al pueblo rural de distintas maneras económicas, políticas y culturales, incluyendo aquellas que los hacen parecer más “tradicionales” de lo que eran.

Estos trabajos tratan sobre la construcción de los paisajes campesinos durante el periodo colonial. Otros académicos han abordado la formación de los campesinados en eventos poscoloniales (p. ej., Takahashi 1972; Wong 1987). Lo que tienen en común es que refutan la necesidad del cambio social del campesinado de la tradición a la modernidad. En cambio, muestran cómo se construyen las formas de la tradición campesina a través de historias contingentes. 
Mi contribución es la de llamar la atención sobre el patrón repetitivo de estas intervenciones estatales. La mayor parte de la literatura representa a los administradores coloniales y a las élites militares y comerciales como si crearan planes económicos racionales y sensibles —es decir, no marcados culturalmente- conforme a sus intereses en ese momento. A los administradores se los muestra reorganizando la sociedad rural para producir y obtener más ingresos, estableciendo alianzas locales que les sirvan a sí mismos o asegurando suministros de arroz para sus propios usos. Si su objetivo es segregar los intereses comerciales y de subsistencia manteniendo a los cultivadores rurales por fuera del comercio, se sugiere que esta es la respuesta más racional a sus propios dilemas económicos. Por su parte, los cultivadores rurales pueden experimentar estos planes de maneras “culturales”, pero los planes administrativos en sí no son descritos como si estuvieran moldeados culturalmente. Esta formulación promueve supuestos en el sentido de que las peculiaridades culturales de los campesinos locales contrastan con las racionalidades cosmopolitas que circulan globalmente. Si en cambio preguntamos por la forma discursiva de los planes coloniales, podemos entender mejor las interacciones locales y globales a través de las cuales se forman el centro y la periferia, el campo y la ciudad, y el norte y el sur globales.

Con el fin de identificar los elementos de los programas agrarios promovidos por el Estado y el sector privado durante la era colonial, me centro en otro tipo de análisis histórico, aquel que se ha usado para examinar la producción de conocimiento sobre las áreas rurales. En particular, existe una importante literatura sobre la representación distorsionada de la aldea asiática en la literatura académica y en aquella orientada a la política pública. Jan Breman (1988) ha mostrado cómo las aldeas asiáticas han sido representadas como cerradas, homogéneas, estáticas y orientadas a la subsistencia, y arguye que esta es una lectura que distorsiona gravemente el registro histórico en el Asia tanto precolonial como colonial (véase también Kemp [1988] y Dove [1985, 1992]). A partir de esta literatura uno puede empezar a ver cómo unos deseos moldeados discursivamente han creado falsas imágenes de los campesinos, que a su vez orientan las formas determinadas de gobernarlos.

La comunidad de la aldea asiática ha sido identificada como el cimiento social de la economía campesina. La literatura sobre el tema se ha enfocado por mucho tiempo en una formación colectiva cerrada que depende de la producción a pequeña escala para satisfacer sus propias necesidades de subsistencia. Se dice que, con muy pocas variaciones, este sistema ha sido repetido ad infinitum a lo largo de la mayor parte de Asia y que se ha reproducido a sí mismo en el curso de muchos siglos 
con poco o ningún cambio [...] La imagen del Antiguo Régimen que así surgió data de informes escritos en las décadas tempranas del siglo XIX por hombres que estaban a cargo de las políticas coloniales y enfrentados con la tarea de concebir un sistema administrativo para las colonias asiáticas. (Breman 1988, i)

Estas lecturas distorsionadas fueron sistémicas, pues apuntaban al hecho de que los escritores y administradores coloniales tenían sus propias ideas sobre el campo y ayudaron a reconstruir el paisaje campesino de acuerdo con estos preconceptos. En las áreas rurales, la Administración colonial era a menudo frágil y, solo con el fin de cumplir adecuadamente con sus tareas, los administradores trataron de construir el tipo de comunidades campesinas que ellos pensaban que podían entender y controlar. Claro que sus reconstrucciones solo podían ser eficaces en la medida en que encontraran alguna causa común con los líderes de la comunidad local, así como con las élites indígenas. Para ellos, valía la pena entender y controlar ciertas áreas más que otras. Aquellas que atraían más la atención colonial fueron apreciadas como modelos en la medida en que evocaban las ideas propias de los administradores sobre los paisajes rurales y, por ende, orientaron proyectos para conocer y administrar otras áreas.

La ventaja de ver el paisaje campesino en relación con los modelos a través de los cuales fue administrado y entendido, no quiere decir que se ignore la variación y la agencia indígena de los aldeanos de Asia Suroriental ${ }^{9}$. No obstante, uno puede tener en cuenta las dinámicas históricas de proliferación: ¿cómo y cuándo las imágenes, reglas y prácticas sacadas de ciertas áreas se convirtieron en modelos para aplicar en otras? Uno también puede preguntar por las exclusiones: ¿cuáles grupos y áreas nunca llegaron a formar parte de la fantasía campesina así delimitada?

Una razón por la cual las interpretaciones y transformaciones coloniales que crearon estos modelos no han sido obvias para los académicos es que quienes describen los paisajes campesinos del siglo XIX los consideran tradicionales, pero esto es algo que no podemos dar por sentado. La “tradición” era una

Es valiosa la advertencia de Elson $(1994,32)$ de no atribuir demasiado poder a la política pública colonial, que a menudo fue incapaz de transformar la sociedad en las formas en que hubiera deseado. Sin embargo, para los propósitos de mi argumento, la imaginación de la sociedad rural es tan importante como la conclusión exitosa de los proyectos coloniales. También vale la pena señalar que muchos de los asuntos más debatidos entre los historiadores que enfatizan la construcción colonial y aquellos que enfatizan la agencia nativa, tales como si la política colonial en Java causó más jerarquía, o más nivelación y más tenencia comunal, o más reivindicaciones de tenencia individual, no son importantes para la historia que estoy tratando de relatar en este ensayo. 
característica central atribuida al campesinado europeo, la cual influyó en las percepciones coloniales en el Asia Suroriental. Con la tradición como la cualidad definitoria de los campesinos, tenía sentido para los observadores ver los paisajes campesinos construidos por el colonialismo como si fueran originales y auténticos, y el malabarismo era imperceptible. Los administradores coloniales miraban el campo y veían a los campesinos de su imaginación, o por lo menos a los campesinos que estaban desvaneciéndose, a los que deseaban ser campesinos o a campesinos con alguna necesidad. Para principios del siglo XX, los programas coloniales habían implantado estas percepciones entre importantes segmentos administrativos del campo en Asia. Además, estaban tan naturalizadas que rara vez se le ocurría a alguien cuestionar su naturaleza tradicional.

Un tercer corpus de literatura debe orientar mi argumentación: las discusiones del siglo XIX de las imágenes y los debates europeos sobre el campo que orientaron a los administradores coloniales. Por consiguiente, tomo un desvío para ir a Europa en mi viaje hacia el paisaje colonial de Java.

\section{Fantasías campesinas 2: en Europa}

Durante mis viajes, que tienden a crear ilusiones [...] seguí encontrándome con la misma arquitectura rural, aquella del campo lorenés de mi infancia: las mismas aldeas agrupadas, los mismos campos sembrados, los mismos maizales, la misma rotación trienal, las mismas imágenes.

Fernand Braudel (1993)

Para la Europa decimonónica, el paisaje campesino ya era un escenario constituido por la memoria y la nostalgia. Esta característica de los paisajes campesinos está todavía con nosotros. Braudel describe el campo europeo como una escena ilusoria incitada por la memoria de la repetición infantil. Sin embargo, su propósito es otro. Está relatando una historia rural real y el paisaje campesino envuelve su intención. Solo puede reflejar el pasado en proceso de desvanecerse, distorsionado y reconstituido a través del lente de la memoria, tal como la tradición en un mundo moderno. Si el problema definitorio al representar a una tribu depende del espectáculo y de su performance de la diferencia cultural (¿los tasaday de Filipinas son auténticos o son actores?), el problema definitorio al representar un paisaje campesino es su dependencia de las debilidades de la memoria para 
reconstruir la continuidad de la tradición que le da forma. Sin embargo, en sí mismo, este proyecto de memoria tiene un alcance y una profundidad limitados en el tiempo por haberse formado en la Europa del siglo XIX. Justo cuando las áreas rurales están experimentando profundas transformaciones “modernizadoras”, vienen a reconfigurarse como repositorios de tradición, siempre repetitivos y jamás plenamente realizados. Es esta aldea en proceso de desvanecimiento lo que los observadores y administradores coloniales llevan a Asia. Dado que siempre se describe a partir de un momento de desplazamiento, es imposible encontrar la aldea original sobre la que estos modelos inexactos fueron construidos.

Las ideas europeas sobre los paisajes campesinos hacen referencia a asuntos que emergieron en diversos tiempos y lugares. Dos escenas imaginadas de la vida campesina fueron particularmente importantes en las discusiones y debates europeos en el siglo XIX. Una ubicaba al campesinado en una situación de atraso paradójica: rebelde pero conservador; la otra veía la construcción del valor cultural dentro del volk, es decir, el pueblo común y corriente. Estos temas se sobrepusieron y viajaron por muchos lugares de la política pública de Estado, de la movilización popular y de la reflexión intelectual. No obstante, parece útil pensarlos en relación con sus referencias enfocadas en Francia y Alemania respectivamente.

La integración decimonónica del campesinado francés a una trayectoria de desarrollo nacional proveyó muchas de las imágenes de los campesinos que se han introducido en discusiones sobre estos como representantes ejemplares de la tradición en un mundo en proceso de modernización. Esta es una manera culturalmente específica de imaginarlos, que depende de nociones de ellos como dependientes y diferentes; son sujetos claves del Estado, pero son difíciles de entender, hasta irracionales. Su tradición crea una paradoja (Dewald y Vardi 1998): por un lado, es una forma de conservadurismo que apoya el statu quo y por otro, se inclina hacia el comportamiento rebelde, desde la rudeza hasta la rebelión abierta.

En el siglo XVIII se desarrolló en Francia una cultura cosmopolita que caracterizó a los cultivadores rurales como ajenos a los ideales de la filosofía de la Ilustración y de la economía burguesa que, se pensaba, eran propios del avance de la civilización. A los campesinos se los aisló del "progreso" de la vida social cosmopolita, de modo que sus costumbres parecían exóticas y arcaicas, hasta salvajes (Lehning 1995). Ya fuera idealizados como nobles o condenados como brutos, los campesinos eran diferentes. En la medida en que las trayectorias cosmopolitas se identificaban como francesas (y algunas veces aparecían como universales), “campesinos” y “franceses” se convirtieron en categorías opuestas.

En el siglo XIX se adelantaron enormes esfuerzos para incluir a las comunidades rurales en la trayectoria nacional francesa, es decir, para convertir a 
estos campesinos imaginados como no franceses en ciudadanos de una nación unificada. La tradición campesina llegó a parecer llena de paradojas. Los campesinos eran objetos clave de la reforma y regulación impuestas por el Estado. Su tradición los hacía difíciles de controlar, pero no solo porque implicaba costumbres locales no reguladas, sino también porque recordaba una historia anterior de rebelión. Y, sin embargo, cuando los campesinos se rebelaron, algunas veces lucharon por la restauración de regímenes de poder previos, en vez de luchar por las transformaciones sociales modernas con las que estaban comprometidos tanto la burguesía urbana como los líderes emergentes de la clase obrera. Sin duda, así fue como muchos comentaristas sociales entendieron las revoluciones de 1848, y vieron a los campesinos como opositores de los reformistas y proletarios, y en favor de jerarquías y derechos anteriores. El comentario social sobre los eventos de 1848 fue particularmente influyente para permitir a los europeos cosmopolitas rotular a los campesinos como "conservadores" (ver, por ejemplo, Marx 1972) ${ }^{10}$.

Esta imagen del campesinado conservador retrógrado fue importante para los administradores en Asia Suroriental. Agobiados por feroces luchas anticoloniales, empezaron a imaginar a los campesinos como posibles simpatizantes del régimen colonial. Parecía que el conflicto era causado por diferencias en términos de civilización, tal como en el caso de la intransigencia islámica. En contraste, la rebeldía de los campesinos conservadores sería principalmente de tipo tradicional y, por ende, controlable. En consecuencia, los administradores instituyeron reformas que esperaban que promovieran la estabilidad y el compromiso con la tierra, que se consideraban rasgos fundamentales del conservatismo campesino, sobre todo en el lugar y en el momento en que imaginaban un campesinado que apoyaría el régimen colonial.

Los campesinos bajo su dominio en Asia Suroriental podían ser fácilmente imaginados como tradicionales, debido a las nociones europeas sobre el atraso de Asia como continente. En el siglo XIX, "Asia” se convirtió en el sitio del despotismo oriental y de las costumbres estáticas feudales (p. ej., Shanin 1990, 6). Hasta el campesinado europeo empezó a parecer asiático en la medida en que fue caracterizado como estático y tradicional. En los debates socialistas sobre el campesinado ruso que tuvieron lugar a finales del siglo XIX, este fue a menudo

10 Marx no estuvo solo en su interpretación; algunos críticos conservadores también consideraron a los campesinos como conservadores. Según Rosener (1994), "Wilhelm Riehl elogió la influencia conservadora de los campesinos durante la Revolución de 1848 y le atribuyó a esta la salvación de los tronos principescos de Alemania" (2). Farr $(1986,9)$ traza imágenes de campesinos conservadores en las novelas con temas rurales populares en Alemania después de 1848. 
descrito como asiático, a diferencia de los obreros rusos. Por ejemplo, para el teórico socialista Plekhanov, los campesinos "representaban Asia, el Oriente y el pasado de la humanidad”, mientras que los obreros "representaban Europa, el Occidente y el futuro de la humanidad" (Shanin 1990, 289). Parece probable que tales discusiones sobre el sello asiático de los campesinos europeos apoyaran, y a la vez disfrazaran, la creciente dominación que los europeos ejercieron sobre los campesinos asiáticos bajo el régimen colonial.

Mientras tanto, otra historia sobre los campesinos se había vuelto importante. En reacción a la hegemonía de la “civilización” francesa en Europa, los alemanes construían una conciencia nacional que dependía de los campesinos como sus principales creadores de valor y continuidad. Los intelectuales alemanes y los voceros nacionalistas trabajaron para descubrir las culturas populares (Völkisch) que, según ellos, representaban un estilo de vida alemán distinto que se remontaba a la prehistoria. Este estilo de vida estaba ejemplificado por las tradiciones campesinas que podían estar en el corazón de la construcción de la nación. Tal como lo manifestó un comentarista social, "el campesino es el futuro de la nación alemana; refresca y rejuvenece constantemente la vida de nuestro pueblo" (Wilhelm Riehl, citado en Rosener 1994, 2). Una nueva rama de estudio conocida como Volkskunde generalizó estos sentimientos para argumentar que se requería examinar la vida campesina con el fin de encontrar la herencia cultural de la nación (Farr 1986). La lingüística histórica y el folclor despegaron como ramas de estudio dedicadas a aprender más sobre el Volk, sus valores y su historia.

Los administradores coloniales en Asia Suroriental se basaron en esta conversación, tanto para imaginar al campesinado como objeto de reflexión, como para romantizar las instituciones y los valores de la aldea. Algunas veces los administradores coloniales consideraron que la vida rural transcurría en “repúblicas” consistentes en aldeas políticamente autónomas, con fuertes tradiciones comunitarias. La nostalgia con la que los administradores observaron la vida rural tenía su origen en estos desarrollos europeos. Con la independencia de las naciones de Asia Suroriental, las ideas nacionalistas alemanas sobre los campesinos llegaron a tener un impacto aún mayor en las discusiones nacionales sobre ellos. Por toda el Asia Suroriental los campesinos se convirtieron en el alma de la nación. Este tema orienta una parte subsiguiente de mi historia. Por ahora me interesan las fantasías coloniales sobre tradiciones campesinas, en cuanto que estas motivaron los intentos de los administradores de aprovechar la paradoja del atraso conservador pero rebelde y de explotar al máximo la herencia de valores comunitarios. 
Estas fueron conversaciones que entrecruzaron a Europa. También es cierto que los administradores coloniales estuvieron influenciados por ideas sobre los paisajes agrarios correspondientes a sus propias trayectorias nacionales e imperiales ${ }^{11}$. De este modo, los españoles que empezaron su colonización de las Filipinas en el siglo XVI estuvieron orientados por una visión previa de un dominio rural en el que la cristianización era el objetivo principal de la subyugación y gobernanza. Los administradores españoles agruparon los asentamientos filipinos, antes dispersos, bajo el sonido de las campanas de las iglesias. Por el contrario, los constructores imperiales del norte de Europa, como aquellos de Inglaterra y Holanda, imaginaron sus adquisiciones coloniales en relación con sus trayectorias de "progreso" mercantilista y económico. Ya en el siglo XVIII, los ingleses se habían librado de la mayoría de sus campesinos; sin embargo, la vida rural permanecía como un lugar para la nostalgia y la imaginación de placeres y alegrías simples. En el siglo XIX, esta nostalgia orientó la política colonial. Holanda, conocida por la temprana especialización de sus campos y el desarrollo del comercio, presentó otra historia de progreso (Vries 1974). Aun durante el declive económico de Holanda en el siglo XIX, los holandeses se imaginaban a sí mismos en relación con su poder comercial previo, y los agricultores de este país fueron representados como emprendedores dinámicos, a semejanza de los “mercaderes calculadores en Ámsterdam” (Gouda 1995, 126)12. Asimismo, los holandeses se involucraron en un "romance rural” utópico (Stoler 2009). En sus proyectos coloniales, los administradores holandeses mezclaron expectativas de progreso y tradición, y los configuraron más a fondo mediante la fantasía del feudalismo asiático.

A fin de explorar más a fondo las fantasías e imposiciones coloniales, regreso a Asia Suroriental, donde existe un lugar que se ha vuelto particularmente bien conocido con respecto a la nostalgia de la élite, tanto extranjera como indígena, por la cultura tradicional y por la masa premoderna de sus campesinos. Es el lugar que John Pemberton (1994) de manera sutil puso entre comillas: “Java”13.

11 En Scott (1998) se puede encontrar una útil discusión sobre los paisajes agrarios a lo largo de Europa.

12 Gouda (1995) escribe que "la representación principal del escenario rural en Holanda [en el siglo XIX] estuvo poblada por agricultores que se especializaban en la producción y exportación bien pagada de queso y mantequilla y con gran presteza respondía a las oscilaciones en la demanda extranjera de productos agrícolas" (126). Los historiadores holandeses representaron su historia agrícola como si hubieran dejado atrás la mayoría de las relaciones feudales al momento de la República del siglo XVII, allanando el camino para la especialización orientada a la exportación y la creación de grandes granjas de capital intensivo, por lo menos en las áreas costeras, durante el siglo XIX (Zanden I994). 


\title{
Fantasías campesinas 3: la construcción de campesinados modelo
}

\begin{abstract}
Esta escena de un enjambre de seres humanos en un entorno ecológico desgastado y a menudo devastado no puede ser más diferente de la Java de principios del siglo XIX. Entonces la isla era un lugar de espesos bosques,

escasamente poblado.
\end{abstract}

R. E. Elson (1994)

En Java los holandeses elaboraron una compleja fantasía híbrida del feudalismo. En el siglo XVIII la fantasía se centró en la construcción de una nobleza híbrida vista como asiática, tanto en su pomposidad y opulencia como en su jerarquía de estatus, pero suficientemente europea en sus ataduras políticas y personales a los centros holandeses de comercio y poder. Jean Taylor (1983) describe la cultura mestiza de la Batavia del siglo XVIII, donde los visitantes europeos encontraron a los oficiales holandeses tan inmersos en códigos jerárquicos de indumentaria, culturas familiares de raza mixta y expectativas aristocráticas de servicio personal, que eran irreconocibles culturalmente. John Pemberton (1994) se refiere a la transformación de los aristócratas javaneses como gobernantes rodeados por supervisores holandeses, privados de poder político, que aprendieron a enfocarse en la ritualidad ensimismada de la vida cotidiana.

Solo hasta el siglo XIX los holandeses empezaron a imaginar a los campesinos como un sitio clave para la reflexión e intervención social ${ }^{14}$. Tal como lo sugiere la cita que abre esta sección, en esa época Java no estaba densamente poblada; los asentamientos rurales se concentraban en los valles fértiles y en las planicies de las tierras bajas, entremezclados con montañas, bosques, pantanos y otras tierras sin cultivar. Algunos historiadores apuntan que el arroz aún no era la comida principal de un gran porcentaje de los javaneses y la gran difusión de los arrozales irrigados todavía estaba por venir (Pelzer 1945, 75). Entonces, la Java de ese momento no era la Java del campesino modelo cuyas imágenes nos llegan hoy.

Los gobernantes javaneses tenían sus propias fantasías campesinas, aun cuando no eran hegemónicas en todas partes. Para los reinos precoloniales del interior central y oriental, el cultivo de arrozales inundados era la característica

\footnotetext{
14 Hasta el inicio del siglo XIX los holandeses contrataron cantidades específicas de bienes de exportación con gobernantes javaneses locales. En este "sistema de comercio", ignoraron la organización de la producción para trabajar con las élites indígenas (Elson 1994, 23).
} 
esencial de las poblaciones sometidas. Tal como ha argumentado Michael Dove (1985), los reinos javaneses crearon una "mitología agroecológica" que caracterizaba la sawah (sistema de cultivo en arrozales inundados) como el sistema agrícola apropiado para el apoyo del reino y para ser incluido en su ámbito de protección, tasación y soberanía. En la Java del siglo X, por ejemplo, los gobernantes ofrecían concesiones de tierras a grupos basados en templos, que consistían en la protección del rey a cambio de convertir su tierra en sawah (Christie 1991; Vickers 1986). Una inscripción del siglo X ofrece una concesión de tierra "[para] que esta se convierta en sawah y que deje de ser un lugar tenebroso" (Vickers 1986,156). Según la lógica de los gobernantes, por fuera de las sawah merodeaban bandidos y prevalecían condiciones inseguras y poco predecibles; el rey ofrecía protección para el comercio, el control del agua y los rituales que buscaban aumentar la fertilidad. La sawah se volvió parte de una estética élite de la naturaleza en cuyo paisaje ordenado se podía sentir la presencia del rey (Day 1994). De modo que el cultivo de sawah fue una característica clave de un modelo de "construcción del campesinado" en el que la población rural podía ser ubicada dentro de la visión jerárquica del reino. Cuando los administradores holandeses se dispusieron a controlar, reformar y beneficiarse de las áreas rurales, se encontraban en gran medida influidos por estos modelos de las élites indígenas. Asimismo, la tradición imaginada de estos modelos les permitió a los holandeses importar de manera inconsciente las preocupaciones europeas sobre el campesinado ${ }^{15}$.

Tres características de la condición campesina parecen particularmente importantes en las formas en que los esquemas coloniales buscaron transformar el paisaje. Primero, el régimen colonial trató de estabilizar las aldeas campesinas convirtiéndolas en unidades territoriales y administrativas. Segundo, el régimen trabajó con ahínco para garantizar la gobernabilidad de los campesinos, es decir, ya fuera manteniendo su docilidad o la naturaleza autolimitada de sus rebeliones. Tercero, los funcionarios coloniales ayudaron a hacer del campo javanés un lugar de tradición y de continuidad imaginada con el pasado antiguo, en contraste con las fuerzas dinámicas del capitalismo holandés. Por el contrario,

15 El gobernador general Bosch usó explícitamente un modelo del campesinado holandés al imaginarse la aldea javanesa; así como con la marke holandesa (distrito aldeano de propiedad comunal), arguyó que la estabilidad de la aldea estaba relacionada con la propiedad comunal (Boomgaard 1989, 8). El siglo XIX fue una época de gran debate sobre la marke en Holanda, en la medida en que el Estado tendía hacia la división de estas tierras manejadas colectivamente, con el fin de beneficiar a los grandes propietarios (Zanden 1994, 32-43). No sorprende que la marke influenciara la política en Java; sin embargo, las imágenes y debates más generales en Europa a menudo fueron tan significativos como determinadas instituciones. 
los javaneses rurales precoloniales eran muy móviles, llevaban consigo armas, peleaban en nombre de sus patrones y no estaban más atados al pasado que cualquier otro grupo ${ }^{16}$. Tomadas en su conjunto, estas tres características contribuyeron en buena medida a definir la cultura política campesina en la imaginación europea decimonónica. Se puede afirmar que, al conferirle estas características a la población rural, la Administración colonial convirtió a los agricultores javaneses en campesinos coloniales modelo.

En el siglo XIX, los administradores coloniales holandeses no tenían actitudes homogéneas hacia el campo javanés. Entre liberales y conservadores se presentaban debates acalorados sobre la mejor manera de gobernar la colonia (Muijzenberg y Wolters 1988). Los liberales creían que la libre empresa estimularía el desarrollo económico, de manera que, para permitirlo, los administradores debían liberar a los cultivadores de sus cargas frente a la jerarquía feudal. Los conservadores tenían más confianza en el poder estatal y trabajaron en conjunto con las élites sociales para estimular la producción. Al tratar el tema de Java, las dos facciones discutieron, particularmente sobre la naturaleza de la tenencia tradicional de la tierra. Los liberales afirmaron que la tenencia privada individual era una tradición javanesa, mientras que los conservadores veían la tenencia comunal como la norma tradicional (Boomgaard 1989). Juntos forjaron un marco discursivo en el que los campesinos eran la base económica y política de la sociedad colonial javanesa. Además, aquellos grupos que podían considerarse campesinos tenían características especiales: cultivaban arrozales y se encontraban asentados en aldeas permanentes, orientadas a la producción. Por su parte, el Estado tenía la responsabilidad de controlar y potenciar a estos campesinos. La meta de la Administración rural holandesa en Java era la de aumentar la estabilidad del campo haciendo de la aldea asociada al cultivo de la sawah una unidad más estable y productiva.

Las ideas conservadoras holandesas del siglo XIX sobre el campo fueron particularmente influenciadas por los historiadores rurales alemanes, quienes situaron los modelos de las aldeas campesinas comunales en la base de los procesos evolutivos humanos (Muijzenberg y Wolters 1988). Por el contrario, las ideas liberales holandesas en Java estuvieron influidas por el corto periodo de dominio inglés en la colonia a comienzos del siglo XIX (1811-1815). El vicegobernador Stamford Raffles siguió la tradición liberal y buscó liberar a la población rural

16 La descripción de Jan Breman (1988) de Java rural en la época colonial temprana enfatiza la movilidad de la población: patronos no territoriales competían por las lealtades de una población que practicaba agricultura itinerante, el comercio requería de los viajes, los trabajadores huían y las aldeas eran solo un tipo de asentamiento. 
de las extorsiones corruptas de la jerarquía feudal, eliminando al intermediario entre el Estado colonial y la aldea. Él hizo de la aldea la unidad básica del sistema tributario y empoderó a los jefes de las aldeas como agentes del Estado colonial ${ }^{17}$. Desde este periodo en adelante, tanto los administradores liberales como los conservadores consideraron la aldea como la unidad básica de la Administración colonial. La gobernanza de la aldea era percibida como la mejor manera de administrar, con poco personal europeo y fondos limitados, una gran masa de población. Este régimen funcionó aún más productivamente para los holandeses bajo el Sistema de Cultivo, programa que fue instaurado en $1830 \mathrm{y}$ duró hasta 1870. Bajo el Sistema de Cultivo, se forzó a los cultivadores rurales no solo a alimentarse a sí mismos sino también a producir cultivos de exportación para el mercado europeo. A través de este programa, el gobernador general Van den Bosch le dio a la Administración un giro hacia la perspectiva conservadora: los cultivos campesinos solo podían ser estimulados por la presión directa del Estado y trabajando de la mano con las élites locales. La mano de obra campesina se ponía a disposición de los proyectos coloniales aprovechando las jerarquías indígenas y sus expectativas de exacción de la fuerza de trabajo. Los investigadores académicos todavía sostienen debates sobre las implicaciones económicas del programa, como por ejemplo si condujo al estancamiento económico o al progreso. Sin embargo, todos están de acuerdo en que los administradores del programa trabajaron con ahínco para crear nuevos tipos de aldeas javanesas y en que el paisaje rural se transformó.

Cierto número de cambios son especialmente relevantes en la construcción del campesinado. En primer lugar, el diseño de las aldeas era regulado y regularizado, puesto que los funcionarios holandeses desaprobaban el desorden del asentamiento javanés ${ }^{18}$. En opinión del primer director de cultivos, "la aldea debe ser de forma cuadrada, con dos o cuatro entradas y protegida por un seto vivo, una zanja o un muro de piedra, y debe poder garantizar la seguridad durante la noche” (Elson 1994, 156). Los caseríos dispersos se centralizaron. "Lo que querían los holandeses era una comunidad de personas permanente y estrictamente definida” (156). A pesar de los obstáculos que se presentaban para

17 Raffles, influenciado por la experiencia inglesa en India, arguyó que la aldea era la unidad de la civilización hindú y que, aunque se había desintegrado de alguna manera, los británicos podían revivirla de forma benevolente (Muijzenberg y Wolters 1988, 3). Ya vemos en escena a un campesino en proceso de desaparición que necesita ser restaurado a través de un modelo a su vez marchitado por el desplazamiento y la memoria.

18 J. van Sevenhoven, el primer director de cultivos, describió las viviendas rurales como "irregulares, desordenadas, situadas aleatoriamente en relación la una a la otra y sin los necesarios medios para asegurarlas" (citado en Elson 1994, 155). 
establecer estas aldeas campesinas ideales, los cambios se hacían y, como nos relata el historiador, para principios del siglo XX las aldeas javanesas se encontraban rodeadas de cercas vivas (157).

En segundo lugar, los líderes de la aldea fueron empoderados y convertidos en administradores locales, y en este proceso se le dio una nueva concreción a la estructura social de la aldea. Desde la perspectiva de las altas autoridades, las aldeas se convirtieron en unidades políticas. Además, en su estructura interna se formaron nuevas divisiones menos flexibles ${ }^{19}$. Mientras tanto, la Administración colonial representó a la aldea como "una pequeña república independiente con una forma de gobierno aristocrático" (residente de Cirebon [1846] citado en Elson 1994, 158).

En tercer lugar, se estableció la policía colonial para frenar la movilidad y la insubordinación rural. Bajo el ojo colonial no era aceptable que los campesinos estuvieran armados. La movilidad se interpretaba como bandidaje o evasión de impuestos y, por consiguiente, como un acto de insubordinación, el cual a su vez era considerado más como una manifestación de malestar social que como un acto de guerra (p. ej., Kartodirdjo 1973). Los jefes javaneses que lideraron rebeliones rurales eran representados como figuras "religiosas" o “milenarias” que carecían del poder necesario para hacer la guerra o la revolución, de manera que, ya fueran obedientes o problemáticos, los campesinos eran siempre tradicionales.

En cuarto lugar, la Administración cortejó a los aristócratas javaneses para mantener el control sobre la mano de obra aldeana ${ }^{20}$. El apoyo a esta aristocracia fortaleció la idea de que las instituciones promovidas para la aldea eran realmente propias del pueblo. Tal como lo escribió en 1831 el gobernador general Van den Bosch, "no debemos interferir en las instituciones domésticas o religiosas [del pueblo], debemos proteger al pueblo de cualquier maltrato y administrarlos hasta donde sea posible conforme a sus propias nociones (citado en Elson 1994, 180). Por supuesto que los campesinos que ellos crearon eran tradicionales.

El Sistema de Cultivo finalizó en 1870, pero los nuevos cambios liberales que se instauraron en ese momento solo confirmaron el tradicionalismo del bución y regulación de tierras. La brecha entre líderes y no líderes se volvió más rígida: "Los campesinos que poseían tierra y no tenían acceso al grupo favorecido tendieron a convertirse en un grupo más homogéneo, maleable y sumiso en su actitud hacia sus superiores y su destino" (Elson 1994, 178).

20 El gobernador general Van den Bosch lo manifestó de manera sucinta: "Estoy tratando de mejorar la seguridad de nuestro asentamiento en esta isla [...] [y] esto debe basarse en una aristocracia bien establecida" (citado en Elson 1994, 180). 
recién formado paisaje campesino. La Ley Agraria de 1870 dividió el territorio entre tierras nativas inalienables y tierras privadas totalmente vendibles; los "nativos" fueron definidos más que nunca como estáticos cultivadores para la subsistencia en contraposición a los emprendedores europeos. Esto marca el inicio del periodo en el que, como argumenta Clifford Geertz (1963), la economía campesina javanesa se atrofió e "involucionó". Probablemente no es necesario revisar los argumentos sobre el estancamiento campesino bajo lo que Geertz llama el sistema corporativo basado en plantaciones. No obstante, es útil recordar que la población rural javanesa aumentó significativamente y se volvió cada vez más difícil conseguir nuevas tierras adecuadas para el cultivo de los arrozales. Los nuevos modelos coloniales y científicos para el manejo del bosque segregaron aún más los bosques y los terrenos de cultivo (Peluso 1992). A principios del siglo XX el campo javanés se había convertido en el modelo de la influyente teoría general de Boeke (1953) sobre las economías duales —segregadas espacialmente- que separan al estático campesinado nativo del colono emprendedor. Los dilemas característicos que nos imaginamos sobre los paisajes y aldeas campesinas estaban firmemente establecidos y adecuados para formar modelos aplicables en otras áreas.

Debido a su definición como tradición rememorada, el campesino modelo es transferible y siempre es parte de una cadena de proliferación. Fue trasladado a las Indias Holandesas y transferido de isla en isla. Thommy Svensson (1990) escribe acerca de una de las primeras transferencias desde el centro y oriente de Java hacia la parte occidental de la isla. Según Svensson, en los 1850 y 1860 la Administración colonial patrocinó una "sawahización” del área del Parahyanagan sundanés, antes de la cual se habían yuxtapuesto y combinado varios tipos de agricultura, incluyendo el cultivo de arroz irrigado y el itinerante. La Administración colonial organizó equipos de trabajo corvée (de servidumbre) para construir los arrozales inundados que podrían estabilizar e incrementar la población en la medida en que también otorgaban nuevos derechos de tenencia de la tierra a las élites locales colaboracionistas. Después de 1870, la Administración también forzó a la población a vivir en aldeas diseñadas con base en el modelo javanés del centro y el oriente. Entonces, fue a partir de estas formas de organización local que surgieron los dilemas de los campesinos sundaneses. Este proceso se repitió en varias áreas de las Indias Holandesas.

Tal vez la fantasía de proliferación más completa sobre los paisajes campesinos javaneses se alcanzó en la colonización agrícola o en los proyectos de "transmigración" que crearon aldeas javanesas en otras islas de Indonesia a principios del siglo XX. La transmigración, que ha continuado hasta el presente, 
busca aliviar la presión demográfica en Java en la medida en que lleva progreso a otras áreas que son consideradas como poco pobladas y subdesarrolladas. Karl Pelzer (1945) se quejó en vísperas de la independencia de Indonesia de que "en toda la discusión sobre la colonización agrícola de las Indias es recurrente la idea de que el objetivo final debe ser el de crear aldeas y comunidades en las islas periféricas que sean duplicados exactos de aquellas en Java” (230). Tal vez pensaba que el campesino javanés podía progresar, pero también consideraba que de todos modos la javanización podía beneficiar de manera importante a las islas periféricas, a través de la formación de paisajes campesinos: "Impulsados por el ejemplo javanés, los pueblos indígenas que hasta este momento han practicado la agricultura itinerante, cambia[rán] al cultivo permanente” (231). Hasta llegó a elogiar el proceso:

La tierra que en el pasado estuvo sin cultivar o fue usada solo ocasionalmente por un cazador, recolector o cultivador itinerante, es fundamentalmente transformada. El bosque desaparece y en su lugar, tan lejos como alcance la vista a divisar, se pueden ver terrenos de arroz irrigado que se extienden, intercalados aquí y allá con aldeas establecidas entre jardines y arboledas de frutales. (231)

Este paisaje fantástico se proyecta hasta donde alcanza la vista y la Administración pueda gobernar.

Los temas que he recopilado en este ensayo son lugares comunes en la literatura sobre la Java de los siglos XVIII y XIX, pero la atención que he puesto en las ficciones y fantasías campesinas les agrega un énfasis algo diferente a historias bien conocidas. Así, uno puede releer el clásico de Clifford Geertz, Agricultural Involution (1963), ignorando por un momento las controversias sobre clase, población y ecología del azúcar para enfocarse en las consecuencias y exclusiones de la construcción del campesino. Dos de los supuestos menos disputados del libro se vuelven problemáticos e interesantes bajo esta perspectiva: ¿por qué se considera que la sawah (cultivo de arroz húmedo) y el swidden (agricultura itinerante) son "sistemas" diferentes y por qué llegó a ser Java el corazón de la historia nacional de Indonesia?

Geertz empieza su discusión acerca de la historia de la Indonesia rural con el contraste entre la sawah y el swidden, y muchos de nosotros crecimos con este contraste como parte de nuestra introducción a los estudios de Asia Suroriental. Había dos clases de personas y lugares: tierras bajas y tierras altas, centro y periferia, campesinos y tribus mezclados con plantaciones y pequeños agricultores emprendedores. Sin embargo, muchos asiáticos surorientales participan hasta 
el día de hoy en prácticas agrícolas que mezclan campos irrigados con cultivos itinerantes, así como en otras prácticas. ¿Cómo llegó a ser tan central y sistemático este contraste en particular? ¿Qué tal si los malayos de la costa de Sarawak que, según Tom Harrisson (1970), tenían una de las economías más eclécticas que me pueda imaginar, se hubieran convertido en los íconos del modo de vida de Asia Suroriental? Sarawak no contaba con una Administración que construyera campesinos. A los Brooke ${ }^{21}$ les gustaba mucho la diferencia tribal, les dieron armas a los iban ${ }^{22}$ y nunca desalentaron la agricultura itinerante. En cambio, en las Indias Holandesas la sawah fue convertida en el centro, en el círculo interno. El eclecticismo agrícola, en lugar de imponerse fue borrado de Java. La agricultura itinerante fue criminalizada y llegó a ser considerada una "economía del ladrón”, y como tal fue empujada hacia las márgenes de la economía y el sistema coloniales (Pelzer 1945). En el texto de Geertz, el swidden también se mueve hacia las márgenes. Después de que el paisaje swidden se introduce como un ecosistema, los practicantes de este sistema agrícola desaparecen de la historia y los trabajadores de las plantaciones y los emprendedores rurales ocupan sus espacios en las islas periféricas. En estas historias de desarrollo y de construcción nacional no hay lugar para un paisaje tribal. De hecho, la sistematicidad atribuida a la agricultura itinerante o swidden no estructura la historia de las islas periféricas y el paisaje swidden es reemplazado por otros arreglos agrícolas. Solo la sawah mantiene su naturaleza sistémica como una guía para la historia social y natural. Algunas poblaciones y paisajes se vuelven marginales y otros, protagonistas centrales en el paisaje rural de la imaginación colonial, aquello que se va replicando. ¿Pueden la integridad y la autonomía del ecosistema sawah articular por sí mismas las reivindicaciones dentro de esta cultura política orientada por la proliferación?

Parece tan obvio que los campesinos javaneses estén en el centro de la historia moderna de Indonesia, que poco vale la pena tratar el tema. No hay duda de que hay factores demográficos y políticos que privilegian a los javaneses en la historia nacional, pero ¿qué pasa con los requisitos de las historias nacionales en sí mismas? "El futuro de Indonesia depende del destino del campesinado javanés”, escribe Gillian Hart $(1986,1)$. Esta afirmación parece no necesitar

21 Se refiere a la dinastía monárquica de los rajahs blancos de Sarawak, descendientes de James Brooke, un inglés que recibió una significativa porción de tierra en 1841, por su colaboración con el sultanato de Brunei (N. de la T.). 
explicación ${ }^{23}$. A fin de cuentas, la mayoría de los indonesios son campesinos javaneses. No obstante, las cifras nunca hablan por sí mismas; si las mayorías se tradujeran en prioridades, veríamos más mujeres y campesinos en nuestras narrativas históricas. ¿Puede ser que la misma campesinidad de los javaneses en la imaginación internacional haya privilegiado su participación en la historia nacional? Esta pregunta me lleva más allá de la época colonial.

A principios del siglo XX, los proyectos coloniales en el campo de Asia Suroriental estaban y a muy bien establecidos, y el reto de hacer gobernables los paisajes asiáticos giró hacia nuevas direcciones. En vez de diferenciar a los campesinos de las tribus, el nuevo reto fue demarcar a los campesinos de sus propios paisajes. Los paisajes, reconcebidos como recursos, se podían explotar con o sin sus campesinados. Por su parte, los campesinos, reconcebidos como poblaciones, podían ser trasladados o reorganizados sin perturbar fundamentalmente el proyecto colonial. Las racializaciones y enumeraciones en los censos de población de principios del siglo XX ayudaron a configurar poblaciones y las burocracias encargadas de manejar los recursos se hicieron cargo de vigilar los paisajes. Esta es la separación que nos condujo al conocimiento internacional de que las poblaciones destruyen los recursos y, bajo las condiciones que este marco ayuda a formar, de hecho lo hacen. Es evidente que hay mucho que decir sobre esto, pero a continuación solo rastreo la transformación del campesinado modelo durante el periodo posterior a la Segunda Guerra Mundial.

\title{
Desarrollo nacional 1: de campesinos a poblaciones
}

\begin{abstract}
El comienzo de la sabiduría al abordar cualquier situación es la acumulación de hechos... El cuadro general de la pobreza y el atraso está delineado en números específicos.
\end{abstract}

Socorro Espiritu y Chester Hunt (1964)

En Agrarian Transformations (Transformaciones agrarias), un trabajo académico clave que delinea las relaciones entre el Estado y la sociedad rural en Asia Suroriental, solo se mencionan los javaneses bajo el encabezamiento "Indonesia" (Hart, Turton y White 1989). Tania Li ha publicado recientemente una respuesta a esta exclusión (1999); su libro originalmente se iba a titular Upland Transformations (Transformaciones de las tierras altas), para hacerle eco al título del libro anterior. 
El libro Social Foundations of Community Development (Los fundamentos sociales del desarrollo comunitario), de Espiritu y Hunt, que acabo de citar, hizo parte de un esfuerzo internacional por suministrar hechos y cifras requeridas para garantizar las mejores trayectorias del desarrollo y la construcción nacional de las nuevas naciones de Asia Suroriental, que emergieron después de la Segunda Guerra Mundial. Los dilemas que enfrentaron estas nuevas naciones diferían de aquellos de sus predecesores coloniales. Se había repudiado el modelo dualista colonial, es decir, la separación necesaria entre la subsistencia nativa y el emprendimiento colonial y, en su lugar, los nuevos Estados-nación entraron a un escenario internacional cada vez más comprometido con un discurso de desarrollo, modernización y mejoramiento de la calidad de vida para todos. Sin embargo, esta visión se debía volver realidad en los paisajes heredados del pasado. En esta sección argumento que los campesinados coloniales modelo llegaron a ocupar el centro de los imaginarios nacionales del futuro, mientras que quienes los estudiaron y describieron, cada vez más olvidaron y borraron las condiciones de su formación como campesinados modelo. Para este proyecto fue clave borrar la incrustación de estos cultivadores en un paisaje natural forjado históricamente. Las ciencias sociales jugaron un papel significativo en reimaginar el campo como un espacio del desarrollo nacional y, para hacerlo, se documentó la tipicidad y se reestructuró a los campesinados modelo como poblaciones nacionales. Mientras tanto, sus paisajes se convirtieron en recursos nacionales y sirvieron de valles fértiles para conceptualizar la intersección de la construcción de la nación y el desarrollo internacional. Sus habitantes fueron imaginados como quienes más necesitaban de la ayuda internacional, debido a su pobreza y tradicionalismo, y como representantes de la ciudadanía, eran sus beneficiarios más apropiados. Sus parcelas se convirtieron en territorios de riquezas nacionales subdesarrolladas. Durante las décadas de 1950 y 1960, se daba por sentado que el desarrollo debía tomar una forma nacional, que tenía como primer objetivo empoderar y enriquecer a las élites nacionales; y que ciertos sectores de la ciudadanía nacional debían ser apaciguados, y en otros casos movilizados, para representar los engaños del desarrollo nacional e internacional como si fueran programas dirigidos al bienestar de la gente. El lugar ideal para desarrollar estas visiones resultó ser los paisajes de los campesinos modelo creados por los programas coloniales.

En primer lugar, los campesinos modelo ya estaban definidos como sujetos y objetos adecuados de la actuación administrativa y, a pesar de un cambio en las metas de esta, seguían siendo objeto del dominio estatal y, por consiguiente, sujetos apropiados de las aspiraciones nacionales del Estado. La historia malaya 
ilustra esto bien, ya que los indios y chinos nunca fueron verdaderos sujetos políticos en la opinión de la Administración colonial, en parte porque no eran vistos como campesinos, aun cuando vivían en el campo. Esto les impidió presentarse a sí mismos como verdaderos sujetos políticos de la nueva nación malaya. Los malayos, en cambio, habían sido moldeados activamente como campesinos, y debido a este estatus estaban listos para convertirse en ciudadanos nacionales y bumiputera, literalmente "hijos de la tierra". El hecho de que muchos de estos ciudadanos hubieran inmigrado recientemente de otras partes de Asia Suroriental no afectó su estatus indígena porque después de todo eran "malayos", es decir, de la raza que los ingleses imaginaron como campesinos propietarios de las parcelas que cultivaban.

En segundo lugar, las habilidades de los campesinos modelo para movilizarse y armar problemas eran respetadas por las administraciones coloniales y este respeto fue transferido a los nuevos Estados-nación. Estos aprendieron de los modelos de gobernanza coloniales que esbozaban las posibilidades de apaciguamiento o de rebelión de los campesinos modelo. Sin embargo, los términos de la gobernanza habían cambiado. Ya nadie estaba seguro del futuro, dado que si se podía derrocar a los grandes poderes coloniales, cualquier cosa podía suceder. Las "revoluciones campesinas” en China, Vietnam y Cuba hacían temblar cada vez más al mundo. Los líderes y movimientos rurales que en un momento dado se habrían desestimado por ser tradicionales, ahora parecían ser los posibles creadores de futuros políticos modernos. Además, las movilizaciones rurales por causas nacionales eran muy importantes, en algunas instancias, para el establecimiento o el sostenimiento de los nuevos regímenes nacionales, aunque también los pusieron en peligro. En este contexto, los nuevos Estados y sus promotores internacionales equipararon los movimientos "populares" a las actividades de los campesinos modelo, ya que a diferencia de las meramente fastidiosas, pero no peligrosas, rebeliones de los grupos étnicos menos centrales, las movilizaciones de los campesinos modelo eran vistas como si emergieran desde adentro de la nación, con el potencial de fortalecerla o de desbaratarla. Como resultado de esta ambivalencia, los campesinos modelo se volvieron actores políticos privilegiados.

En tercer lugar, los trabajos agrícolas de los campesinos modelo que habían sido diseñados para facilitar el control y la intervención se convirtieron en escenarios del desarrollo nacional de los recursos. Se revirtieron las estrategias para la estabilización de la propiedad y la intensificación de la agricultura que habían creado las fincas aprobadas por la Administración colonial. En los lugares donde los gobiernos coloniales habían acordonado las tierras nativas, los 
Gobiernos nacionales universalizaron las leyes de propiedad y volvieron disponibles todas las tierras para la explotación de los recursos. En estos mismos sitios donde los gobiernos coloniales habían demandado la intensificación laboral, los Gobiernos nacionales aplicaron el milagro de la intensificación tecnológica, y demostraron así el potencial nacional para la modernización. Que los campesinos perdieran sus tierras y sus modos de vida en este proceso era irrelevante para el desarrollo de los recursos.

En cuarto lugar, la densidad de las poblaciones de campesinos modelo los privilegió dentro de la retórica de la representación nacional, por cuanto ellos constituían las masas de la nación, concebida desde una perspectiva populista. Si todo individuo merece una oportunidad para progresar, los grupos más numerosos merecen más oportunidades que los otros. Los campesinos modelo eran numerosos y hasta estaban hacinados. Pero allí se presentaba una ambivalencia: si bien una población grande significa una sociedad saludable, también amenaza con agotar los recursos y reproducir la pobreza. El privilegio de los campesinos modelo, en cuanto a la demografía y a la acción política, se formó por el deseo de la nación en desarrollo de controlarlos, incluso cuando les otorgaba beneficios especiales.

La investigación y las políticas que surgieron de esta ambivalencia sobre la demografía ilustran las maneras en que los campesinos, en su momento tan cuidadosamente construidos, dejaron de ser reconocidos como tales. En la formación de los paisajes campesinos, las administraciones coloniales trabajaron con ahínco para aumentar las poblaciones. A finales del siglo XIX, una de las metas más explícitas de los ingleses en la península de Malaca fue la de incrementar la población malaya (Lim 1977, 16). Para promover el crecimiento de la población, estimularon la inmigración, nuevos vínculos estables con la tierra y los lugares de las aldeas, y la extensión y exclusividad de los cultivos permanentes para la subsistencia. La lógica de incrementar las poblaciones centrales no está del todo ausente en políticas más recientes (Ong 1990), pero fue particularmente en los programas de límites a la población, que emergieron como parte del aparato de desarrollo internacional, que los campesinos fueron enumerados, concentrados y eliminados, literalmente, de sus historias ${ }^{24}$. La reproducción se representaba, por una parte, como un asunto de estadísticas aglomeradas y por otra, como una decisión contraceptiva individual; no había lugar para la especificidad de los

24 Limitar la población no era una idea nueva, ya que estaba bien desarrollada en el Asia Suroriental colonial de principios del siglo XX. Sin embargo, se convirtió en un problema nacional bajo supervisión internacional después de la Segunda Guerra Mundial, y en este sentido, estimuló una gran cantidad de nuevo pensamiento, investigación y política pública. 
paisajes de los campesinos modelo. No obstante, en la construcción de estos paisajes las historias de los programas para aumentar la población proporcionaban los parámetros ocultos a partir de los cuales las masas y los individuos iban a ser contados y controlados. De manera que las características de los campesinados modelo eran a la vez ocultadas y universalizadas, como los rasgos naturales de cualquier población rural nacional.

Desde los años cincuenta hasta la década de 1970, Asia Suroriental rural fue el lugar de una incesante recopilación de datos en esta línea, y proliferaron las descripciones de aldeas representadas como "típicas” nacionalmente. Solamente los antropólogos tribalistas más dedicados estudiaron los grupos menos centrales. La energía más bien se dirigió hacia quienes eran considerados los representantes rurales de la nación. Lo que tienen estos estudios en común es la certeza sobre la necesidad de recolectar información concreta, neutral y objetiva. Los expertos internacionales son más invisibles que nunca y muchos no sienten ni siquiera la necesidad de argüir teóricamente, pues el llamado a describir la vida rural es suficiente. Se asume que estamos de acuerdo con la importancia de la modernización y el desarrollo, el problema de la pobreza y las desventajas de la tradición. En el contexto de este acuerdo, necesitamos las cifras y las gráficas que nos dicen qué intervenciones presentan una ventaja comparativa. Mediante estas cifras y ecuaciones, que representan a la población rural en un espacio internacionalmente enrarecido, por fuera de la dinámica de las culturas, sus luchas e historias, se hace posible construir a los ciudadanos nacionales. Y aunque parezca bien estar indignado con las ciencias sociales del desarrollo, que después de tantas intervenciones razonadas (necesidades básicas, resistencia campesina, cultura, clase, teoría del sistema-mundo, conservación, conocimiento indígena y mucho más) sigue estando apoyada hasta el día de hoy, de manera recalcitrante y sin la más mínima reflexión, por instituciones poderosas en todo el mundo, probablemente valga la pena tratar de recordar que por lo menos en un momento dado pudo haberse acompañado de un sentido de esperanza, de avance internacional, sin la constricción de la diferencia cultural imaginada, y de logro y orgullo nacional.

Los fondos para el desarrollo hicieron posible el flujo de beneficios para los campesinos modelo. En algunas áreas se intentó llevar a cabo una reforma agraria limitada, pero más comúnmente se despejaron "nuevas tierras” que fueron ofrecidas a los campesinos como colonizadores. En Malasia, los programas de la Autoridad Federal de Desarrollo Territorial (Federal Land Development Authority [Felda]) reasentaron a los campesinos malayos en plantaciones forestales; en Indonesia, la transmigración javanesa siguió formando aldeas campesinas a 
lo largo del archipiélago, y en Filipinas, los agricultores arrendatarios de Luzón colonizaron tierras en Mindanao, Mindoro y otras islas. Nadie se preocupó por quienes vivían en esas tierras antes de que fueran "despejadas" para los campesinos modelo. En algunos casos, los pagos directos también llegaron a las aldeas de los campesinos como una práctica política clientelista. En Malasia, por ejemplo, los residentes de aldeas que apoyan el partido gobernante reciben beneficios clientelistas (Scott 1985). Así como sucedió con el despeje de nuevas tierras, la meta no era acabar con las desigualdades en la aldea sino crear alianzas entre los campesinos modelos y las élites nacionales y apaciguar a los campesinos solo lo suficiente para prevenir su movilización contra el Estado.

Esta estrategia de construir lealtad nacional entre el campesinado modelo, imaginado como residente de un "campo" amorfo, moldeó la política internacional, incluyendo la política exterior de los Estados Unidos. Con el fin de examinar este aspecto me refiero ahora a las Filipinas. La Administración colonial de Estados Unidos en las Filipinas elaboró una retórica sobre los agricultores como constructores de nación, que influenció el desarrollo nacional después de la Segunda Guerra Mundial, tanto en Filipinas como alrededor del mundo. Los agricultores protagonistas de la historia nacional podían surgir del campesinado modelo colonial, mirar hacia el futuro y usar su enorme solidez para construir naciones democráticas. Como sujetos y objetos de la nación, ellos se convirtieron en los personajes de las historias en las que la autonomía nacional y el desarrollo internacional neocolonial se entrelazan inextricablemente.

\section{Desarrollo nacional 2: agricultores y fronteras}

Yo creo que el propósito real de la reforma agraria es el de crear hombres libres, hombres que son dueños de la tierra que cultivan, hombres que están dispuestos a dar sus vidas en defensa de su derecho natural, porque su derecho natural es, a fin de cuentas, suyo. Yo creo que el propósito fundamental de la reforma agraria es crear una nación que perdure.

Conrado Estrella (1969)

De todos los gobernantes coloniales de Asia Suroriental, Estados Unidos fue probablemente el menos interesado en restaurar la fantasía del feudalismo perdido. Al final del siglo XIX, este país se convirtió en la autoridad colonial en Filipinas 
por la fuerza de las armas y se encargó de buena parte del paisaje campesino diseñado por los españoles, quienes habían tratado de obligar a sus sujetos filipinos dispersos a abandonar la agricultura itinerante y asentarse en aldeas centralizadas. Los administradores coloniales también propiciaron el establecimiento de núcleos de arrendatarios y aparceros densamente poblados, al entregar estos campos y aldeas estabilizadas como feudos; al fortalecer la posición de las familias principales; y, algo más tarde, al permitir la participación de los mestizos chinos con pretensiones comerciales en el círculo de los terratenientes poderosos. Los norteamericanos, lo mismo que sus predecesores españoles, consideraron estos núcleos campesinos como un factor central de la gobernanza colonial; $\mathrm{y}$, como aquellos, creían que colaborar con la élite terrateniente era clave para el éxito del Gobierno. No obstante, se distinguieron de sus predecesores mediante un proyecto ideológico en el que el colonialismo era concebido como un programa de entrenamiento para la construcción de una nación democrática. En este proyecto, el campesino modelo era el "hombre común”, o tao en la lengua tagala, de modo que se necesitaba cambiar el valor simbólico de los campesinos modelo, pues al dejar de ser imaginados como sujetos tradicionales del feudalismo, se les pidió convertirse en portadores de las lealtades nacionales democráticas.

Con esta apariencia democrática, los campesinos modelo se volvieron agricultores arrendatarios y la superación de la condición arrendataria se convirtió en un gran desafío del desarrollo democrático filipino. Este "problema” de los agricultores arrendatarios acaparó una buena parte de la atención de la Administración colonial de Estados Unidos. Los lazos personalistas entre el arrendatario y el propietario fueron condenados por atrasados, opresivos y antidemocráticos. Se argumentó que los agricultores necesitaban su propia tierra si iban a desarrollar un compromiso con un Estado nación planificado. Sin embargo, fue imposible desplazar a la élite propietaria de tierra porque sus integrantes eran los colaboradores clave que necesitaba Estados Unidos para gobernar.

Un compromiso fue “despejar nuevas tierras”, particularmente en Mindanao que era "la frontera" del desarrollo. No importaba el hecho de que ya vivieran allí musulmanes y poblaciones "no cristianas" de las tierras altas, pues, tal como los amerindios en la frontera de Estados Unidos, no fueron imaginados como posibles ciudadanos nacionales ${ }^{25}$. Los campesinos modelo que se trasladaban hacia Mindanao desde Luzón jugaron el papel de los colonos en el oeste norteamericano,

25 Al describir este proyecto de reasentamiento, Pelzer (1945) menciona el problema de las tribus. "En ciertas partes de las islas", escribe, "las tribus locales no-cristianas resienten la infiltración de los filipinos de las tierras bajas y atacan a los colonos" (113), y sugiere que el Gobierno debe apartar las reservaciones tribales y recapitular la fantasía del paisaje estadounidense. 
con lo que avanzaron en el proyecto nacional pendiente. El asentamiento en aldeas se representó como arcaico e innecesario debido a las nuevas posibilidades de la colonización de la frontera (Pelzer 1945, 110-112). Es así como el discurso de reubicación contrasta fuertemente con los proyectos de reasentamiento javaneses diseñados por esa misma época en las Indias Holandesas. Mientras que los campesinos javaneses fueron enviados para reproducir el paisaje de la aldea tradicional en los nuevos territorios, los agricultores de Luzón se convirtieron en los nuevos colonizadores democráticos e innovadores de la frontera pseudonacional. Este proyecto recapitulaba de manera consciente las historias estadounidenses sobre el desarrollo de esa nación: primero, el escape de la Europa tradicional y después la difusión de las jerarquías de la costa del este hacia la frontera salvaje pero democrática. Este es el proceso, o por lo menos así lo relata el mito fundacional, que construyó el carácter nacional norteamericano. La Administración colonial les inculcó esta historia a los filipinos para poder construir el tipo de proyecto nacional que los administradores estadounidenses se imaginaban.

La colonización pionera de Mindanao probablemente sirvió más para apoyar la narrativa de los administradores que para abordar la insatisfacción en las áreas pobladas por los campesinos modelo. De hecho, durante este periodo muy pocos agricultores se trasladaron de Luzón a Mindanao. Además, los campesinos modelo terminaron desarrollando mecanismos más efectivos de organización. Cuando Estados Unidos perdió Filipinas ante Japón durante la Segunda Guerra Mundial, los agricultores de Luzón Central conformaron el movimiento antijaponés Hukbalahap. Con el regreso de la Administración de Estados Unidos, los huks, como se llamaban popularmente, se convirtieron en objeto de una masiva supresión militar, pero esta supresión dirigida hacia comunidades campesinas enteras popularizó las rebeliones agrarias y redobló sus apuestas. Este fue el contexto rural que Estados Unidos le entregó a la nueva nación filipina el día de su Independencia, el 4 de julio de 1946 (fecha de Independencia nacional que comparte con Estados Unidos).

El Gobierno filipino siguió de cerca los lineamientos de Estados Unidos, continuó la represión militar en el campo luzonero y al mismo tiempo trabajó en el desarrollo de un programa para aplacar las demandas de los agricultores de Luzón. Fue entonces en ese primer momento que la reforma agraria empezó a figurar en la agenda de la construcción de la nación filipina. La historia del destino de las propuestas de reforma agraria de finales de los años cuarenta y principios de los cincuenta ilustra el surgimiento del campesino modelo, con apariencia de agricultor común, como un protagonista privilegiado al estar en el centro de la historia nacional y como un objeto de preocupación especial por el control social. 
Inmediatamente después de la Segunda Guerra Mundial, la política exterior estadounidense favorecía de manera entusiasta la reforma agraria. Estados Unidos, asustado por la movilización revolucionaria en China, estaba listo para apaciguar a los campesinos, y los promotores de la reforma agraria creían que esta marcaría la diferencia entre una nación en desarrollo, que podía oscilar hacia el comunismo o hacia el mundo libre. Los asesores norteamericanos pensaron que con la promoción de la reforma agraria habían alcanzado algún éxito en el desmantelamiento de las estructuras de poder de la oposición y en prevenir un giro hacia la izquierda en Japón, Corea y Taiwán (Putzel 1992). En Filipinas, los asesores estadounidenses también sugirieron la realización de una reforma agraria. El Ejército norteamericano difundió la promesa de una reforma agraria y el Cuerpo de Desarrollo Económico (Economic Development Corps) les ofreció tanto a los rebeldes huks como a sus potenciales seguidores, un asentamiento de colonización en Mindanao (Olson 1974, 80-81). En 1950, el Acuerdo Foster-Quirino condicionó la ayuda económica a la supervisión de la reforma por parte de Estados Unidos. En 1952, un asesor estadounidense de la reforma agraria expidió un informe que ofreció un fuerte respaldo a la abolición del arrendamiento de la tierra:

El alivio de la carga opresiva del caciquismo (latifundismo feudal) se ha buscado y ha sido denegado por demasiado tiempo [...] Los arrendatarios demandan que se rectifiquen las inequidades básicas que caracterizan el modelo agrario [...] es evidente que, hasta que se remedie, el sistema de tenencia de la tierra se erige como un obstáculo que impide cualquier empeño de Estados Unidos para desarrollar una economía estable y democrática. (Informe Hardie, citado en Monk 1996, 182-183)

Los oligarcas filipinos no apoyaron la posición de Estados Unidos, la cual había sido concebida por los liberales del Nuevo Trato (el New Deal estadounidense del presidente Franklin Roosevelt) y el presidente Quirino calificó a la reforma agraria estadounidense como un "insulto nacional” (Putzel 1992, 91). Sin embargo, la posición de Estados Unidos desencadenó un debate entre los políticos filipinos en el que los "liberales" de la reforma agraria se enfrentaron contra los propietarios “conservadores”. Estos últimos argumentaron que el progreso económico requería apoyo del Gobierno a la libre empresa y a la propiedad privada; la reforma agraria debía estimular la productividad, pero no redistribuir tierra $^{26}$. Con el apoyo liberal estadounidense, Ramon Magsaysay se lanzó a la

26 Nótese que los rótulos de liberal y conservador se usan de manera algo diferente en este debate del siglo XX, bajo la influencia norteamericana, que en los discursos europeos del siglo XIX, tal como los desacuerdos coloniales holandeses. 
Presidencia con una plataforma de reforma agraria sólida y ganó. Se demostró que la reforma agraria era popular entre los votantes. No obstante, ¿estaba Estados Unidos realmente dispuesto a atacar a sus aliados de la élite, los propietarios de tierra? Nadie tuvo la oportunidad de averiguarlo porque, para el momento en que Magsaysay asumió la Presidencia en 1954, el ambiente político en Washington había cambiado. Los promotores estadounidenses de la reforma agraria fueron retirados de sus puestos en Filipinas y sus reemplazos ofrecieron menos apoyo a los programas liberales. Además, el éxito de la campaña militar contra los huks (irónicamente dirigida por el mismo Magsaysay cuando ocupaba una posición previa como secretario de Defensa Nacional) significó que los huks dejaron de ser considerados una gran amenaza para la seguridad (Olson 1974, 84). El proyecto de ley que Magsaysay logró elaborar y hacer aprobar en el Congreso filipino terminó privilegiando a los terratenientes. El tamaño de las propiedades sujetas a ser expropiadas era tan extenso, que la ley no afectó prácticamente a ningún propietario, e incluso las haciendas más grandes solo podían ser redistribuidas ¡si la mayoría de los arrendatarios solicitaban su expropiación! (Putzel 1992, 92). La retórica de la reforma agraria todavía llamaba la atención nacional, pero no produjo ninguna mejora concreta para los agricultores arrendatarios.

De hecho, este precedente creó las bases para una historia sobre las iniciativas de reforma agraria en Filipinas. La reforma agraria —es decir, aquella que aborda las condiciones específicas de los campesinados modelo- continuó discutiéndose como si fuera el rasgo esencial para construir una nación democrática. Los liberales intentaron aliviar las inequidades sociales en el campo mientras que los conservadores las redirigieron en beneficio de los propietarios de tierras (Putzel 1992). Aunque se aprobó una serie de proyectos de ley de reforma agraria, ninguno de ellos produjo un cambio importante. La colonización de las "nuevas tierras" continuaba su curso, desplazando a los habitantes previos, quienes carecían de visibilidad nacional. Como solución a la pobreza se seguían sugiriendo los insumos tecnológicos. Los grandes propietarios de tierra, quienes habían renovado sus alianzas con los patrocinadores estadounidenses, siguieron dominando la política. La reforma agraria se convirtió en un programa permanente que consistía en hablar mucho y, de vez en cuando, llevar a cabo algunas acciones para aplacar a los pobres. Cada nuevo programa o proyecto de ley reconocía esta realidad y se declaraba como una ruptura con el pasado feudal (en 1967 el presidente Marcos dijo: “Tenemos que poner fin a las décadas de rodeos y dilataciones en la aplicación de las leyes de reforma agraria” [citado en Estrella 
1969, 79] $)^{27}$. La retórica del desarrollo nacional requirió que se prestara atención a las necesidades de los agricultores pobres, pero la organización de la política reprodujo sus posiciones subordinadas. Tal vez la ventaja para los campesinos modelo fue que se tomaron en serio sus preocupaciones. La desventaja fue que no pudieron hacer ninguno de los cambios básicos que demandaban ${ }^{28}$.

Probablemente fue en este contexto que en las áreas habitadas por los campesinos modelo se desarrollaron la "política cotidiana" y la "resistencia cotidiana”. Me refiero a un influyente marco teórico elaborado por James Scott y Benedict Kerkvliet, y explicado en relación con las Filipinas en un libro muy informativo titulado Everyday Politics in the Philippines (La politica cotidiana en Filipinas) (Kerkvliet 1990; ver también Scott y Kerkvliet 1986). La aplicación de este marco teórico requiere que se restaure la campesinidad a las poblaciones modelo, cuestión que discuto en la próxima sección. También depende de la historia de los campesinados modelo en la construcción de la nación. A través de esta historia, todo lo que hacen los campesinos modelo, incluso lo más mundano, se ha vuelto "político", es decir, capaz de relacionarse con los asuntos concernientes a la construcción de la nación. Por otro lado, las actividades cotidianas de los grupos "tribales" de las tierras altas son vistas como "culturales" y aquellas de los musulmanes filipinos, como "religiosas". En el análisis sobre la construcción de la nación en la ciencia política, solo el campesino modelo puede ser un actor político consistente. No arguyo que lo personal no sea político, sino más bien que no es casual que Kerkvliet haya escogido una aldea de agricultores arrendatarios en Luzón Central para representar a las Filipinas y entender su política cotidiana. La manera en que las prácticas de los campesinos modelo se vuelven políticas está moldeada por su prominencia en las historias de construcción de la nación.

En este contexto pareciera correcto argüir que hay un continuo de actos de resistencia que van desde la dilatación, el disimulo y la evasión, hasta las protestas y denuncias. Los campesinos modelo han ganado su identidad en relación con una larga historia de vigilancia. Desde la perspectiva de aquellos que los controlan, todo lo que ellos hacen es por definición un acto de docilidad o de rebeldía. Lo que falta en el análisis es un sentido de la especificidad histórica de esta clase

27 A Marcos le interesaba desmantelar el poder de algunas familias propietarias de tierras claves, para así empoderar a sus compinches y fortalecer su régimen personalista (Hawes 1987). Sin embargo, la retórica de empoderamiento de los pequeños agricultores para participar en el proceso político nacional significaba para él, así como para otros, hablar de construcción de la nación y no de un plan de cambio organizacional. Aquino al poder y a lo largo de su régimen, mostrando cómo los debates entre liberales y conservadores han mantenido la discusión de la reforma agraria en el centro de la política filipina, sin adelantar realmente ningún programa de reforma significativo. 
de politización. A este respecto, Kerkvliet arguye que los campesinos filipinos que estudió sienten que tienen derecho a su sustento y dignidad. Es probable que estos agricultores arrendatarios de Luzón Central estén al corriente de su importancia en las discusiones sobre la nación en las Filipinas. Su sentido del derecho es una respuesta lógica a su posición elevada como protagonistas populistas; sus reclamos son fáciles de hacer porque resuenan con aquellos de las élites nacionalistas que arguyen sobre los modos de vida y la dignidad al invocar sus paisajes y cuerpos. Tal como lo afirma Kerkvliet, el sentido de derecho de los campesinos no es signo de una economía moral universal pues se basa en la historia y la experiencia. Sugiero que también nos habla de la cultura de la política nacional en la que estos agricultores arrendatarios juegan un papel privilegiado. Solo bajo esta perspectiva es que uno puede entender por qué estos aldeanos pobres se toman la molestia de participar en la política convencional a través de manifestaciones, peticiones y otras protestas formales (p. ej., Kerkvliet 1990, 141-142). El Gobierno de verdad los escucha. Cuando en 1981 unos arrendatarios se tomaron un pedazo de tierra que no se usaba, efectivamente fueron tenidos en cuenta, aunque no ganaron (190-198). En respuesta a sus quejas, la tierra fue vendida y redistribuida, pero esto no benefició a los pobres. Esta situación es un epítome de su papel alegórico actual: como protagonistas nacionales, pueden expresarse y estimular la reforma, pero es improbable que sea la reforma que desean. Sus protestas, efectivas e inefectivas a la vez, se convierten en "resistencia" antes que en caminos hacia el cambio. Mi lectura no apunta hacia la desventaja común y corriente, como lo podría considerar Kerkvliet, sino a un privilegio históricamente específico de carácter ambivalente y no muy enriquecedor.

El marco teórico de Scott y Kerkvliet (1986) es importante no solo porque especifica los dilemas de los campesinos modelo de Asia Suroriental bajo regímenes de desarrollo nacional, sino porque interviene en contra de los programas de recopilación de datos que documentan estas poblaciones nacionales privilegiadas, pero que borran su construcción histórica. Los estudios campesinos revivieron la conciencia de los académicos del carácter campesino de estas poblaciones. Trajeron al centro de la discusión al campesino como un actor histórico, e hicieron posible imaginar historias nacionales que trabajan en su favor o en su contra y no solo a costa de ellos. Al abordar el mundo, así como la academia, los estudios campesinos mostraron que en el tercer mundo rural la supervivencia iba más allá de los conflictos de la guerra fría que inspiraron la intervención de Estados Unidos en lugares como Vietnam. Asimismo, vistos desde la perspectiva de las preocupaciones actuales sobre la diversidad cultural y la marginalidad, también es posible decir que los estudios campesinos universalizaron y naturalizaron 
aún más los dilemas de los campesinos modelo, lo que hace difícil ver qué más pasaba en el campo del tercer mundo, además de la reproducción o la disolución de la campesinidad alegórica.

\section{El redescubrimiento del campesino}

El campesino [...] no opera una empresa en el sentido económico; administra un hogar, no un negocio.

Eric Wolf (1966)

A finales de los sesenta, los analistas académicos redescubrieron la naturaleza campesina de las poblaciones centrales de las naciones del tercer mundo, y las rescataron de su invisibilización cultural y de su masificación en los textos producidos en el marco de la "modernización como desarrollo". Los campesinos se volvieron un nuevo objeto de análisis en la medida en que los investigadores académicos, al describir las comunidades rurales en el tercer mundo, empezaron a compararlas con las de los campesinos de la Europa moderna temprana (Dalton 1972). Otros académicos, influidos por estas comparaciones, empezaron a reconsiderar las apuestas de los “campesinos” en las protestas y rebeliones tanto en el tercer mundo como en la historia europea (Hobsbawm 1973). En este creciente entusiasmo muchas disciplinas académicas estuvieron representadas. Los historiadores sociales, por ejemplo, describieron a los campesinos como sujetos cuyas historias políticas habían recibido poca atención, mientras que los antropólogos estudiaron los valores campesinos, así como la ecología cultural de las sociedades campesinas (Silverman 1979). Eric Wolf (1966) argumentó que los antropólogos debían ocuparse de los campesinos porque, al ser productores de excedentes que se les transferían a las élites, ilustraban importantes tipos de jerarquías económicas y políticas. Mientras tanto, una traducción al inglés del trabajo de A. V. Chayanov, un economista ruso que escribió acerca de las economías basadas en familias campesinas en la Rusia de principios del siglo XX, estimuló la proliferación de análisis académicos sobre las dinámicas de las economías rurales del tercer mundo de ese momento (1966). En vez de desaparecer dentro de la economía industrial, como habían predicho los teóricos marxistas y no-marxistas, los campesinos habían mantenido una presencia continua en el tercer mundo rural. De repente, la investigación se interesó por las características sociales y económicas de los campesinos. 
Desde el principio, las preguntas centrales se enfocaron en la forma como se relacionan los campesinos con las economías de mercado, las relaciones de clase capitalistas y la represión del Estado; los estudios campesinos se entrelazaron así con teorías sobre la desigualdad global. Los tipos de rebeliones agrarias que habían interesado a los expertos de la política exterior de Estados Unidos empezaron a llamar la atención de académicos que tenían una actitud más comprensiva, lo cual llevó a discusiones sobre la rebelión y la conciencia campesinas. Se desataron peleas acerca de quiénes eran campesinos (Shanin 1990) y si maximizaban las ganancias o eran adversos al riesgo (Popkin 1979; Scott 1976). En los años ochenta, la atención giró hacia la "resistencia cotidiana". De otra parte, la ecología política y los estudios subalternos empezaron a desarrollarse y los estudios campesinos se convirtieron en una fuente vital de construcción de teoría y de debate intelectual en las ciencias sociales.

Los estudios campesinos estimularon el interés en la historia de los paisajes rurales (p. ej., Roseberry 1993) y se llegó a comprender mejor distintos aspectos de la problemática. Por ejemplo, se hizo visible la importancia inmanente de la propiedad en la definición de los paisajes rurales una vez los campesinos fueron vistos como participantes activos en la producción de la historia. También se consideró que las relaciones de los campesinos con el ambiente están mediadas por el acceso a los recursos de acuerdo con la clase, lo cual es un avance clave en el marco de la discusión sobre poblaciones versus recursos de muchos teóricos del desarrollo nacional. De hecho, esta idea ayudó al surgimiento de campos estrechamente relacionados como la ecología social, la ecología política y la ecología de la liberación (Bryant y Bailey 1997; Guha 1994; Peet y Watts 1996). En estos campos, la conservación se toma en cuenta junto con el acceso diferencial a los recursos, las políticas administrativas y de coerción del Estado, y las historias de negociación y lucha política. Las adaptaciones ecológicas de largo plazo de las comunidades campesinas con frecuencia ofrecen modelos para reflexionar sobre las relaciones sostenibles entre los seres humanos y los ambientes naturales. Una razón por la cual desarrollar una apreciación de las fortalezas y los límites de los estudios campesinos de los setenta, ochenta y principios de los noventa es que sus ideas enmarcan la manera como se entiende el ambiente en Asia Suroriental y aún más allá.

Los "campesinos" de los estudios campesinos tienen un amplio alcance comparativo y una gran profundidad histórica que los hace sujetos interesantes para la discusión ${ }^{29}$. Lo que para la mayoría de los analistas agrupa escenarios diversos y hace que valga la pena hablar de sus habitantes es su contraste con 
estereotipos de la "modernidad", ya sean las racionalidades de mercado, los valores de la Ilustración o la mercantilización capitalista de la tierra y el trabajo. El hecho de que los campesinos no hayan desaparecido a pesar de las coacciones de las modernidades imaginadas es testimonio de la profundidad histórica y la continuidad de sus estilos de vida. No era que los académicos ignoraran el cambio: el objetivo de muchos analistas era estudiar a los campesinos en un mundo "cambiante". Sin embargo, la característica clave que hizo de los campesinos un lugar para pensar el cambio fue la importancia de la continuidad y la reproducción en la constitución de las comunidades campesinas.

El énfasis en la continuidad y la reproducción como la herencia de los campesinos estimuló la formación de modelos de campesinidad. En este sentido era fácil que las nociones de tradición asociadas con ciertos momentos y lugares se naturalizaran como concomitantes con la situación campesina. En áreas donde los Gobiernos nacionales ya consideraban ciertas poblaciones campesinas modelo como representantes del hombre común y corriente de la nación, los investigadores académicos siguieron privilegiando a estas poblaciones en sus propios modelos campesinos, puesto que no solo había datos disponibles sobre ellos, sino que ya era claro que desempeñaban un papel en las economías políticas y las historias nacionales. Las características de estos grupos "modelo" fueron aceptadas como las de la población rural tradicional. Se pasaron por alto las historias sobre cómo estas poblaciones en particular se habían vuelto centrales para las narrativas nacionales. Además, estas características fueron a menudo naturalizadas como necesarias para la reproducción social en sí misma ${ }^{30}$.

En parte, el marco teórico de la continuidad y la reproducción campesinas es creado y naturalizado con base en presupuestos no estudiados sobre las familias y los hogares. Para muchos académicos, los campesinos son hogares agrícolas basados en la familia; tanto las familias como los hogares se reproducen, y al hacerlo, extienden en el tiempo la vida social campesina. Esta conexión entre familia, hogar y reproducción social parece obvia, necesaria y natural en muchos estudios sobre los campesinos.

Una de las maneras de explorar este problema es hacer un seguimiento a la influencia de Chayanov (1966) al definir a los campesinos a través de la

ochenta se descubrió que los africanos coloniales, una vez considerados prototribus, eran campesinos (Isaacman 1993, 229).

30 Los teóricos de la sociedad campesina con frecuencia basan sus nociones sobre la política y la cultura campesinas exclusivamente en las necesidades de sobrevivencia con tecnología limitada, la reproducción biológica y las características generales de jerarquía social, y descuidan la variedad de alternativas culturales que también juegan un papel destacable en estos aspectos (p. ej., Langton 1998). 
explotación agrícola familiar. Chayanov argumentó que la peculiaridad de los campesinos tenía que ver con la producción y el consumo familiar; los teóricos del campesinado, ya sea que estén o no de acuerdo con las ideas de este autor, han tendido a tratar los hogares organizados alrededor de la familia o encabezados por un hombre como unidades irreducibles y como componentes de la diferenciación por clase, cultura, moralidad, toma de decisiones, política populista y rebelión. ¿Por qué empiezan los analistas con los hogares? Los hogares agrícolas basados en la familia forman los paisajes "campesinos" porque se da por sentado que las familias mágicamente unificadas, aunque dominadas por el hombre, son agrupaciones humanas, y no se pone atención a las condiciones bajo las cuales estas familias son reivindicadas y constituidas. ¿Será que los paisajes campesinos son reproducidos a través de la constitución, históricamente específica, de las familias?

Las académicas feministas han hecho precisamente esta pregunta, y han llamado la atención no solo sobre la diversidad, el dinamismo interno y la inestabilidad de los hogares agrícolas familiares, sino sobre las circunstancias históricas bajo las cuales aun los que parecen más estables deben reconstruirse una y otra vez. El estudio de Diana Wong, Peasants in the Making (Campesinos en formación), de 1987, es relevante. En contra de la idea habitual de que la Revolución Verde de Malasia debilitó a las comunidades campesinas tradicionales, Wong arguye que formó campesinos al segregar a las familias como unidades de producción. Wong utilizó una definición especializada del término "campesino" e incluyó solo fincas de propiedad y trabajo familiar. Mis "alegorías campesinas”, que incorporan a aparceros y arrendatarios, tienden una red más amplia. Sin embargo, la definición de Wong se contrapone al modelo del campesinado de Chayanov, en el que la reproducción de las familias corresponde a la reproducción de la sociedad tradicional. En el área arrocera que estudió Wong, las fincas familiares fueron creadas gracias a la alta productividad de la doble cosecha por efecto de la Revolución Verde, la disminución de los requisitos de mano de obra debido al uso de cosechadoras mecánicas y la siembra al voleo, y la recuperación de parcelas alguna vez arrendadas a terceros. Antes de la Revolución Verde, cultivar significaba que los pobres trabajaban para los ricos y que ninguna finca podía sobrevivir como un proyecto de una sola familia. Cuando las nuevas tecnologías redujeron la necesidad de mano de obra, se desarrollaron formas de autonomía familiar que acabaron con este tipo de integración social jerárquica. Wong describe a los campesinos malayos que estudió como si estuvieran situados en un momento histórico no reproductivo en el que parecía probable que la "campesinización”, a la vez que emergía, daría paso a la formación de una clase capitalista. Por otro lado, es también un momento en el 
que se puede imaginar la reproducción. La granja familiar era tradicional en la fantasía nacional y al lograrla, aun por un momento, los campesinos podían hablar desde la posición privilegiada de una profundidad histórica imaginada.

Al escribir sobre esta misma región, Gillian Hart (1992) aborda el problema de la naturalización de los hogares desde otro punto de vista. Ella argumenta que en los setenta las agencias del Estado malasio querían crear hogares agrícolas unificados; sin embargo, a pesar de sus intentos este sueño siguió siendo una ilusión, por lo menos para los pobres, y opacó las diferencias entre las estrategias económicas de los hombres y las mujeres. En los setenta y los ochenta, las cuadrillas de trabajo integradas por mujeres pobres organizaron enfrentamientos directos con los propietarios de tierras, mientras que los hombres pobres, atrapados en redes clientelares, se limitaban a refunfuñar individualmente. De hecho, el ideal nacional emergente del hogar familiar dirigido por el hombre fue utilizado para criticar la ineptitud de los hombres pobres y además para intimidarlos y disuadirlos de que se unieran a las protestas de sus esposas (Hart 1991).

Los análisis de Wong y Hart desafían el estatus de la reproducción del hogar familiar campesino que se daba por sentado, y vuelcan la atención hacia las historias bajo las cuales se moldea e imagina la campesinidad. Nos devuelven la posibilidad de estudiar las fantasías, así como las realidades campesinas, y abren una discusión sobre su formación, tanto en Malasia como en los estudios campesinos.

\section{El paisaje de la resistencia}

Al fin y al cabo, uno no puede esperar que el pez hable sobre el agua.

James Scott (1985)

La Administración colonial inglesa creó un paisaje racializado en la península de Malaca $^{31}$. Después de considerar algunas pocas ideas iniciales sobre los asentamientos agrícolas chinos e indios, los administradores ingleses dirigieron sus fuerzas para atraer colonos del archipiélago indonesio y convertirlos, junto con los locales, en un "campesinado malayo" asentado en aldeas (Lim 1977, 19-20),

31 Sarawak y Sabah, los estados de Malasia Oriental, no fueron activamente "campesinizados" bajo el dominio europeo. Generalmente, sus ciudadanos "demasiado tribales" son todavía ignorados en la literatura nacional, así como en los estudios campesinos. 
mientras que los chinos e indios ocuparían otros nichos. Ansiosos por proteger los intereses europeos en las plantaciones agrícolas, los ingleses desalentaron activamente a los campesinos malayos respecto a la siembra de cultivos comerciales, especialmente (después de 1905) el caucho, que era la mercancía destacada por su éxito desmedido. Aunque de todas maneras los minifundistas malayos sembraron caucho con gran entusiasmo, la política colonial trató de disuadirlos en todo momento (Lim 1977). Los administradores ingleses querían que los malayos cultivaran arroz, que era visto como el cultivo campesino tradicional. Estaban preocupados de que los malayos vendieran su tierra y abandonaran la agricultura campesina y la vida en aldeas. El Código de Tierras Selangor de 1891 introdujo la idea de preservar las tierras propias o tierras consuetudinarias (customary lands) que no podían ser vendidas, excepto a otros malayos. La idea alcanzó plena expresión en 1913 con la Promulgación de las Reservas Malayas, que estableció reservas de tierra disponibles únicamente para aquellos de raza y religión malayas (Lim 1977, 103-138). En el proceso, la ley definió legalmente quién podía considerarse malayo y, por ende, campesino (Ong 1987, 20).

A pesar del compromiso de los ingleses con la subsistencia agrícola, la autonomía económica casi nunca era una elección. Wong (1987, 31-39) describe cómo las élites malayas en los llanos del norte de Kedah, apoyadas por las políticas comerciales de Inglaterra, centraron su atención en la colonización de tierras, construyendo canales de drenaje y reclamando grandes propiedades para ser cultivadas por los arrendatarios. Desde el inicio, los agricultores fueron agobiados por las obligaciones hacia los propietarios de las tierras; incluso cuando enfrentaban las dificultades de desmontar nuevos campos, siempre estaban en deuda. Históricamente, la deuda ha sido una característica central de los modos de vida rurales y no un deterioro reciente de la tradición, como lo imaginaban las autoridades coloniales.

La autonomía política de las aldeas imaginada por algunos modelos campesinos nunca fue posible. Desde el inicio del dominio británico en el siglo XIX, las aldeas malayas fueron sitios improvisados para la negociación de la Administración colonial. Los inmigrantes fueron concentrados, las tierras, registradas y las prácticas legales e ilegales fueron puestas en orden. Shamsul (1986) describe los asentamientos establecidos en las tierras baldías, alrededor de las plantaciones europeas en Selangor, por medio de la agricultura itinerante ilegal. Cuando la tierra fue registrada para conformar "aldeas", la agricultura itinerante no se pudo practicar más. También describe cómo los jefes locales, los penghulu, que fueron convertidos por los ingleses en mediadores coloniales, se encargaron de crear aldeas. Cuando los agricultores de una aldea sembraban caucho a pesar de su 
prohibición por las reglas coloniales, el penghulu reemplazaba al líder de la aldea y la unía a otras, a una unidad más dócil. Tales eventos producían facciones y movimientos de oposición en las aldeas, los cuales después de la independencia se transfirieron a la política partidista. Los líderes aldeanos que querían establecer lazos con el régimen, apoyaban al partido dominante, la Organización Nacional de Malayos Unidos (United Malays National Organization [UMNO]), y se convertían en intermediarios del clientelismo que permeaba las relaciones de este partido con los aldeanos malayos. Los opositores se unieron al Partido Islámico Pan-Malasia (Parti Islam Se-Malaysia [PAS]), que desarrolló un discurso de superioridad religiosa y moral con el cual oponerse a los patrones clientelistas. En particular, los hombres de las aldeas imaginaban su agencia como figuras políticas locales, mediante un diálogo de doble vía, entre el clientelismo y la conformidad con el Estado, de una parte y, de otra, la oposición religiosa y moral a la conducta de los empoderados por el clientelismo que acataban el sistema ${ }^{32}$.

Al moverse dentro de discursos de moralidad, ya sea en conformidad o en oposición, los hombres aldeanos evocaron las retóricas nacionales sobre la importancia de la herencia malaya. Shamsul (1986) señala que la Nueva Política Económica implantada en 1971 fundía el “desarrollo” con el progreso económico y racial para los malayos (190-195). En este contexto, las evocaciones aldeanas de raza, religión y familia podían basarse en la legitimidad trascendente de las directrices morales nacionales. Además, las ansiedades urbanas por la pérdida de la tradición volvieron aún más influyentes las retóricas de la herencia moral. El estudio de Aihwa Ong (1987) sobre las mujeres malayas rurales que trabajaban en las fábricas electrónicas en Selangor a finales de los setenta mostró la importancia de las preocupaciones nacionales sobre la conducta moral de estas mujeres. En el contexto de las ansiedades públicas, había una enorme presión sobre las jóvenes trabajadoras para que se consideraran ellas mismas constante y eternamente campesinas. Se esperaba que se pensaran como hijas obedientes, enviaran su dinero a casa, mantuvieran identidades solidarias de clase y raza, y se prepararan para ingresar de nuevo a la vida aldeana después de que fueran despedidas. Las jóvenes no se oponían totalmente a ser consideradas modernas,

32 Shamsul (1986) presenta la historia de una mujer, la nuera de un importante líder que se convirtió en una política local influyente con el apoyo de su suegro (1986, 177-183), lo cual muestra que participar en la política partidaria ha sido posible para las mujeres. Sin embargo, esta mujer, promocionada como un caso especial, necesitaba trabajar principalmente con hombres en un lenguaje predominantemente masculino. Hart (1991) también arguye que la política partidaria malaya ha privilegiado a los hombres en relaciones clientelistas que excluyen a las mujeres. 
minah karan (literalmente "minahs eléctricas")33, o por lo menos espíritus independientes que sabían algo sobre la ciudad, así como de la aldea. Sin embargo, en la retórica que giraba alrededor de ellas, se combinaron los ideales de los roles de género adecuados, de las familias morales y de la tradición campesina malaya, y proveyeron así un poderoso imaginario de la decencia campesina. Tanto los aldeanos como los citadinos tenían modos de usar estas posturas morales.

La década de 1970 también marcó el momento en el cual la Revolución Verde transformó el campo dedicado a los cultivos de arroz. En Kedah, el Plan de Irrigación Muda permitió dos cosechas de arroz irrigado. Se introdujeron variedades de alto rendimiento, se promovió el uso de fertilizantes y se hicieron disponibles la mecanización y el crédito. La mayoría de los comentaristas están de acuerdo en que, durante los primeros años del programa, estos cambios aumentaron la productividad, así como los ingresos y oportunidades económicas en el campo (p. ej., Scott 1985, 65). Sin embargo, para el final de la década, las ventajas diferenciales para los ricos y los pobres se habían vuelto más obvias y algunos de los pobres sin empleo habían empezado a abandonar la zona. Esta fue la época en la que Diana Wong (1987) encontró una consolidación de las familias autónomas como unidades de trabajo y de socialidad. En el contexto de la emergencia de discursos nacionales sobre la familia y la tradición malayas, es posible imaginar el poder de las reivindicaciones basadas en la familia, dentro y más allá de la política aldeana.

Todo esto ofrece un marco a través del cual releer el libro Weapons of the Weak (Las armas de los débiles), una importante contribución de James Scott (1985) a los estudios campesinos. Scott presenta una descripción cuidadosa de una aldea kedah afectada por la Revolución Verde, en la cual se muestra sensible a las quejas que los pobres expresan sobre el comportamiento de los ricos. Ilustra cómo a través de estas quejas demuestran que son capaces de ver más allá de las mistificaciones económicas que las élites usan para justificar su búsqueda de riqueza. En vez de sentirse intimidados por las ideas hegemónicas sobre el estatus social, los pobres son dóciles en público, pero usan momentos “detrás de bambalinas” para quejarse y obstaculizar las exigencias de pagos por parte de la élite. Esta obra ha influenciado las apreciaciones académicas sobre las perspectivas subalternas, no solo porque llama la atención sobre la agencia de los débiles, sino porque sugiere que los aldeanos pobres pueden decir verdades sobre las ideologías de la élite y desmitificar así el capitalismo y el poder del Estado. Además,

33 Minah se refiere a las jóvenes rurales que migran a trabajar en las fábricas urbanas en Malasia. Karan tiene dos acepciones: la corriente eléctrica y la sexualidad eléctrica (N. de la T). 
las verdades que cuentan se basan en su manera de entender la historia y la tradición, que critica el presente desde la perspectiva de un pasado imaginado. Para los investigadores académicos, el poder de esta postura emana de su coincidencia con la de los intelectuales enfocados en la justicia social, quienes también se oponen al capitalismo y el poder del Estado, y llaman la atención sobre las alternativas históricas. El hecho de que los campesinos pobres malayos hagan lo mismo, les permite a los lectores simpatizar y, a la vez, aprender de ellos.

En su descripción de la aldea, Scott asume que los hogares basados en la familia son unidades, no solo de producción y consumo, sino de todo tipo de acción social y política; es cuidadoso en distinguir entre hogares diferencialmente ricos, pero no nos dice casi nada sobre los asuntos internos ni las historias que hacen que las familias consideradas como hogares parezcan ser unidades. Además, el comentario social que recibe de los campesinos habla de las posiciones de clase tal como son entendidas desde la perspectiva de los representantes de las familias, que son a menudo, aunque no siempre, hombres casados.

¿Bajo qué circunstancias pueden los hombres casados hablar por las familias? ¿Por qué pueden inspirarse en pasados imaginados? He sugerido que varios procesos históricos se unieron para producir esta poderosa retórica a través de la cual los hombres de la aldea pueden imaginar su agencia, tanto en cumplimiento de los proyectos de modernización del Estado como en oposición a estos. Igual que Wong (1987), Scott concluye que las familias han consolidado su mano de obra en respuesta a las oportunidades de la Revolución Verde. Y como Shamsul (1986), encuentra que la participación política privilegia a los hombres malayos, quienes reciben beneficios clientelistas del Estado por ser cabezas de hogar, pero también, en su condición de miembros del partido de oposición, se quejan de las mismas políticas públicas en reuniones caracterizadas por la moralidad. Al jugar estos papeles, los hombres aprenden a apoyarse en una retórica nacional cargada de tradición y moralidad. De manera que "la recordada aldea”, a la que se refieren en sus comentarios críticos, es tanto su propia respuesta a las condiciones locales como el uso creativo de un marco discursivo más generalizado.

En esta aldea la particularidad de la perspectiva de los hombres casados es sugerida por unas cuantas anécdotas que relata Scott (1985), como las siguientes: cuando los hombres jóvenes reaccionan con rabia frente a una incursión de un camión con arroz en el camino a la aldea, por cuanto amenaza los ingresos de los jóvenes que transportan costales de arroz, las cabezas de hogar mayores se reúnen para discutir la situación, evitar nuevas incursiones y regañar a los muchachos por cobrar demasiado (212-220). Cuando las mujeres dedicadas al trasplante de plántulas de arroz boicotean a los agricultores que emplean cosechadoras 
mecánicas para recoger su arroz (privando a los aldeanos de empleo), los hombres casados -incluyendo el esposo de una de las organizadoras-describen la acción como cháchara, un sinsentido (249-253) ${ }^{34}$. En cada uno de estos casos, las cabezas de hogar masculinas convierten las acciones más beligerantes de otros en su propia política simbólica y elaboran ideas sobre el comportamiento adecuado que les permite negociar entre ellos, pero que da por sentado su poder sobre quienes carecen de los privilegios históricos particulares como hombres, como malayos y como aquellos que pueden revindicar el ser representantes, tanto de las familias como de la tradición.

Sugiero que el poder alegórico de estas perspectivas campesinas se deriva de un momento histórico en particular, en el cual la reproducción pudo ser imaginada como un fantasma del pasado que persigue a la modernidad capitalista en la voz de las cabezas de hogar masculinas definidas racialmente. Estas hablan en representación de la subalternidad, la pobreza y la injusticia, dado que "representan” a las familias actuales y a las comunidades imaginadas del pasado.

No hay nada malo en referirse a este momento y a estas perspectivas, ya que se trata de un asunto poderoso. Al hacer uso de voces como estas, los estudios campesinos evocan ricas historias de desigualdad y resistencia. No obstante, plantean preguntas acerca de ¿a quién se deja por fuera?, ¿qué otras historias podríamos querer contar junto con las alegorías campesinas?

Para contrastar, consideremos las perspectivas políticas que académicos y activistas retoman de un acontecimiento que sucedió en la política de Malasia muy poco después: las protestas de los penan "tribales" contra la tala forestal (Brosius 2003). Demasiado marginales para acceder al ámbito de la alegoría campesina, los penan no pudieron adherirse al discurso del legado nacional y la moralidad tradicional. Ellos no son los agricultores de arroz malayos que imaginan los políticos nacionales como la población histórica y representativa de la nación. Parecen estar tan fuera y tan lejos de la órbita del pensamiento nacional, que los políticos malayos concluyeron precipitadamente que algunos extranjeros seguramente los animaban, y arguyeron que la causa de los penan debía ser un montaje internacional, y tildaron la campaña de ser un caso de "ecoimperialismo”. De hecho, activistas de los países del norte simpatizaban con los penan sin tener en cuenta que son malasios. Las alegorías tribales los representaban como miembros de una cultura sin Estado y que podían ser clave para una alianza mundial que eludiera por completo las jurisdicciones de los Estados-nación.

34 En una respuesta a Scott, Hart (1991) arguye que en cualquier evaluación que se haga de la resistencia, las protestas directas de las mujeres dedicadas al trasplante de plántulas de arroz deben ser contrastadas con los refunfuños indirectos de los hombres. 
Por el contario, los hombres malayos casados, en su condición de campesinos, hablan en nombre de la larga historia del dominio del Estado y de la explotación por la élite. Hablan en nombre de la familia nacional y la familia aldeana, de los ancestros del pasado y los niños del futuro. Hablan en nombre de los paisajes establecidos desde hace mucho tiempo, que solo pueden preservarse si las élites vuelven a cumplir con su responsabilidad moral con los pobres, pues a pesar de las contradicciones implícitas, ellos representan al pueblo.

\section{El regreso de las tribus}

Existen muchas lecciones ecológicas para ser aprendidas a partir de la comprensión de la estructura de las sociedades de pequeña escala, pero no son necesariamente aquellas sobre las que algunos influyentes gurús verdes llaman la atención, o aquellas que aprobarían.

Roy Ellen (1986)

A finales de los años ochenta, cuando la preocupación de los ambientalistas por la conservación de lugares silvestres alrededor del mundo alcanzó proporciones descomunales, se creó un nuevo espacio para la discusión acerca de las "tribus" que viven en aquellos lugares supuestamente salvajes. La nueva discusión se basó en las historias tempranas de las campañas organizativas por los derechos indígenas de las Primeras Naciones en el Cuarto Mundo, y también adquirió una particularidad ambientalista. En este contexto, las tribus son definidas a partir de su diferencia cultural en relación con los grupos no tribales. Los asuntos relacionados con la clase social, el colonialismo, el nacionalismo y el dominio del Estado son relegados en la medida en que los asuntos de la cultura y la naturaleza toman la palabra.

Este cambio de agenda no ha sido visto de manera positiva por la mayoría de los expertos en el tercer mundo rural, que están embebidos en los estudios campesinos o de desarrollo nacional. A los tribalistas se los critica no solo por inventar las culturas de otros pueblos, sino por tener una visión "poco realista” del paisaje rural, lo cual de hecho a menudo es así. No obstante, esta confusión entre el relato de historias y los objetos de las historias puede hacernos reflexionar sobre los paisajes campesinos que los académicos han llegado a considerar como los verdaderos. Los estudios campesinos y sus herederos en las ecologías por la 
justicia social también se basan en la fantasía y el relato de cuentos. La alegoría es la que hace posible a los académicos y activistas considerar nuestro pasado y futuro común a través de los paisajes rurales.

Dicho esto, es difícil tener mucha simpatía por algunas formas de tribalismo, como es el caso del que existe solo en la realidad virtual y en los medios de comunicación. Quizás en la publicidad es donde se ha hecho más prominente, como se puede ver en la controvertida campaña de Body Shop que publicita su trabajo con los indígenas kayapo (Corry 1993). Estos son blancos fáciles para la crítica, como lo son también las visiones optimistas de un globalismo mundial, presentada por algunos activistas tribalistas, que glorifican las posibilidades de las conexiones de Internet entre los activistas, ignorando los requisitos sociales y técnicos que las hacen significativas.

No obstante, las alegorías tribales han permitido a los activistas forjar visiones y planes prometedores. Como mencioné al inicio de este ensayo, las yuxtaposiciones de las alegorías tribales y campesinas han moldeado el entusiasmo del ambientalismo en Asia Suroriental. En Indonesia, Malasia y Filipinas, los populismos ambientalistas han reunido temas de justicia social nacional con asuntos internacionales de deforestación, contaminación, mercados verdes y más. Los movimientos son conscientemente nacionalistas. Lo que sorprende es la transformación de los viejos nacionalismos populistas para incluir a las minorías culturales. Las agendas agrarias tribalistas han expandido el significado del nacionalismo populista al traer nuevos grupos (habitantes de las tierras altas y del bosque) y nuevos temas (conocimiento indígena, protección de la biodiversidad, integridad comunitaria) al ámbito de la discusión nacionalista favorable a su inclusión ${ }^{35}$.

Algunas organizaciones internacionales también han empezado a promover agendas híbridas campesino-tribales. Por ejemplo, la conservación basada en la comunidad (CBC) reúne ideales de mejoramiento de los modos de vida campesinos y de manejo medioambiental tribal, en un único modelo internacional ${ }^{36}$. Este modelo promueve la idea de que las comunidades locales pueden manejar los recursos naturales. Los promotores internacionales de los proyectos de la CBC

35 En los años ochenta, Michael Dove llamaba campesinos a los kantu' del Kalimantan Occidental, Indonesia; más recientemente ha escrito que pertenecen a una tribu. Dove (comunicación personal) señala que esto se debe a que escribía en el primer caso para una audiencia orientada hacia el desarrollo y para otra de ambientalistas en el segundo, y se dirigía a cada una en sus respectivos términos. Esto enfatiza la importancia de las alegorías que portan los términos para mover a los lectores a que imaginen a los actores rurales dentro de escenarios globales orientados hacia la acción. 
vienen de las filas de quienes han construido su prestigio en el campo del desarrollo campesino orientado hacia la comunidad. Sin embargo, la CBC los anima a que pongan más atención a los bosques y otros "lugares silvestres", generalmente ignorados en las alegorías campesinas clásicas. El Programa de Alivio de la Pobreza de la Fundación Ford, un patrocinador de la CBC, tomó su modelo de los proyectos de irrigación a pequeña escala en las áreas de los campesinos modelo de Filipinas; después el programa consideró los derechos al bosque en Indonesia (Coward 2005). El programa aportaba una arquitectura "campesina" para imaginar la movilización comunitaria, con el fin de abordar el problema ambiental "tribal". No obstante, para jugar un papel en la conservación forestal, la "comunidad local" ha sido reimaginada como marcada culturalmente y naturalmente sabia - es decir, tribal—, en vez de desfavorecida económica y educativamente —es decir, campesina-. Las comunidades locales de la CBC son híbridos entre el pensamiento campesinista y el tribalista.

Los híbridos y las yuxtaposiciones crean nuevas posibilidades para las alegorías agrarias que transforman nuestras historias sobre los futuros globales. A continuación concluyo con una revisión de los elementos claves de las alegorías conocidas.

\section{Campesinos, agricultores y tribus: algunos futuros de la naturaleza}

Los agricultores son quienes solo usan los recursos e, idealmente, maximizan su economía y contribuyen al producto interno bruto. Sabemos sobre sus futuros porque los economistas nos hablan de ellos. Con razón, Vandana Shiva (1989) se queja de estos mismos economistas al considerar que sus enumeraciones dejan por fuera tanto el trabajo "no económico" de las mujeres, como el trabajo regenerativo de la naturaleza. Es justo decir que sus cuentos han embrollado a Gobiernos y comunidades rurales en planes que promueven la deforestación, desertificación, erosión, salinización y contaminación, además de la pobreza y explotación laboral. Sin embargo, a principios del siglo XXI, tanto los campesinos como las tribus deben evaluarse en comparación con las contribuciones globales de los agricultores. Por supuesto que estoy hablando de figuras alegóricas y no de personas en particular. 
Las figuras campesinas que se rescatan de las poblaciones nacionales aportan largas historias sobre la cultura nacional y la lucha por la subsistencia y por la dignidad humana, así como por perturbar de manera insolente los planes de las élites y del Estado que no los toman en cuenta. Los campesinos contribuyen con los paisajes tranquilos y fructíferos que distinguen a nuestras naciones. Dicen sus defensores que no nos podemos deshacer de ellos, porque son luchadores tenaces y decididos; son aliados en nuestras luchas por un mejor destino nacional. Esconden su resistencia detrás de su sumisión, y por lo tanto nos recuerdan las dificultades y los compromisos con la equidad social en el largo plazo. Además, sus paisajes tienen la estabilidad duradera que todos queremos para la tierra. Las figuras campesinas son quienes mejor entienden el balance de la naturaleza y los requisitos de los sistemas que permiten la continuidad de la subsistencia, de la comunidad y de las extracciones de la élite por muchos años y generaciones. Por otra parte, tienen ecosistemas y sistemas socio-político-económicos. Si la tierra está hecha de naciones y ecosistemas, necesitamos campesinos para que la sostengan. La alegoría de los campesinos nos da la capacidad para imaginar la sostenibilidad a nivel global.

Sin embargo, se piensa que las tribus, al igual que los científicos, son quienes más conocen sobre los secretos de la naturaleza. Y se imagina que son las guardianas de la biodiversidad y que los científicos no pueden enumerar o mantenerla sin su ayuda. Las figuras de las alegorías tribales saben cómo construir paisajes y comunidades que no separen a las personas de su medio ambiente, rechazan las dicotomías de salvaje versus doméstico o de los seres humanos versus la naturaleza. Por lo tanto, nos ayudan a aprender a respetar la variedad y la riqueza de la naturaleza. Las figuras tribales eluden las jurisdicciones de las naciones establecidas y por lo tanto van más allá de las fronteras y nos enseñan a pensar globalmente y a actuar localmente. En síntesis, constituyen los nodos culturales de las redes globales. Si somos serios en el estudio de los problemas ambientales que van más allá de las jurisdicciones nacionales, tenemos que abrazar estas alegorías tribales y seguir su ejemplo.

Después de la Segunda Guerra Mundial, una nueva ola de ambientalismo internacional unió la agenda científica de la ecología de los sistemas naturales con la agenda moral de preservación del balance de la naturaleza, y dio paso a la construcción de un movimiento social (Taylor y Buttel 1992). Dentro de este movimiento, el campesino nacional fue a menudo utilizado como protagonista para imaginar las posibilidades de una estabilidad y reproducción social y natural duraderas. Lo ilimitado de estos análisis de sistemas fue clave para el éxito de una mejor caracterización del futuro global: tal como los sistemas naturales se 
apropian de la energía de cualquier parte, incluyendo el espacio extraterrestre, y la reciclan para su propia reproducción, del mismo modo, los sistemas sociales interconectados y jerárquicos aún pueden suministrar modelos para el reciclaje social productivo y la estabilidad dentro de nichos paralelos pero autorreproductivos, incluyendo las naciones. El entrecruzamiento de lo natural y lo social en el paisaje agrícola campesino hace que su fértil estabilidad sea un modelo particularmente atrayente de futuros sostenibles.

El rechazo científico de la estabilidad del ecosistema en los años ochenta permeó muy lentamente a la comunidad ambientalista, y para horror de los científicos ecologistas, muchos activistas todavía hablan del "balance de la naturaleza”. No obstante, sin sus fundamentos científicos, la legitimidad del movimiento ambiental estaría en problemas (Worster 1994). Cuando el movimiento trastabiló, una nueva forma de ciencia lo recogió de nuevo: la biología de la conservación. Los biólogos conservacionistas aportaron una teoría y un método científico a otra causa moral, la protección de la biodiversidad. Sin embargo, los objetos y supuestos del ambientalismo formado en esta ciencia y moralidad diferían de aquellos de la era de los ecosistemas. En ese momento aparecieron las tribus en el escenario.

En primer lugar, el enfoque viró hacia los paisajes "silvestres". La mayoría de los biólogos conservacionistas suponen una incompatibilidad entre el uso humano y la capacidad de la naturaleza para florecer. Sin embargo, los paisajes tribales parecen representar una excepción prometedora a la incompatibilidad entre el ser humano y la naturaleza. ¿Es esta una grieta a través de la cual los humanos podemos entrar en una naturaleza renovada? Los biólogos conservacionistas puristas todavía están horrorizados por la idea, pues los paisajes campesinos se encuentran claramente más allá del límite.

En segundo lugar, la meta de preservar la biodiversidad solo se puede lograr a la escala global en la que sea medible la diversidad, pues las naciones no significan nada. La construcción del globalismo es un asunto polémico, donde muchos expertos hacen llamados por un espacio científico de observación dominado por el norte y que no esté marcado culturalmente. Los defensores de lo tribal se han hecho escuchar al presentar una alternativa: una red global que conecta varios nodos de cultura y naturaleza con un espíritu de respeto por la diversidad.

En contraste, los campesinos parecen no tener nada que decir sobre estos temas. Por el contrario, siguen reclamando con su voz ambientalista la justicia social y la responsabilidad nacional.

Llamar la atención sobre las alegorías campesinas y tribales no me lleva a evaluar o a desestimar sus reivindicaciones en competencia. Sin embargo, tal vez este sea el inicio de otro tipo de discusión. 


\section{Agradecimientos}

Este ensayo fue originalmente escrito en 1995. Fue concebido como el inicio de una conversación y me siento privilegiada de que haya estimulado intercambios con varios académicos generosos con sus observaciones. Benedict Anderson, Donald Moore y James Scott contribuyeron con comentarios detallados y críticos a todo el manuscrito. Barbara Andaya, Warwick Anderson, Paulla Ebron, Corinne Hayden, Celia Lowe, Vicente Raphael, Craig Reynolds y Ann Stoler me ofrecieron referencias, sugerencias y advertencias sobre mi enfoque. Estoy muy agradecida con todos ellos por su ayuda y estoy perfectamente consciente de que en la versión final no pude integrar plenamente sus sugerencias.

Traducción del inglés

Andy Klatt

Traductor oficial en Colombia y traductor certificado en Estados Unidos andy.klatt@gmail.com

María Clemencia Ramírez Antropóloga, investigadora honoraria del ICANH clema15@yahoo.com

\section{Referencias}

Baviskar, Amita. 2003. "Tribal Politics and Discourses of Indian Enviromentalism”. En Nature in the Global South. Environmental Projects in South and Southeast Asia, editado por Paul Greenough y Anna Lowenhaupt Tsing, 289-318. Durham: Duke University Press.

Boeke, J. H. 1953. Economics and Economic Policy of Dual Societies. Nueva York: Institute of Pacific Relations.

Boomgaard, Peter. 1989. Between Sovereign Domain and Servile Tenure: The Development of Rights to Land in Java, 1780-1870. Ámsterdam: Free University Press.

Braudel, Fernand. 1993. A History of Civilizations. Traducido por Richard Mayne. Nueva York: Penguin.
Breman, Jan. 1988. The Shattered Image: Construction and Desconstruction of the Village in Colonial Asia. Dodrect: Foris.

Broad, Robin y John Cavanagh. 1993. Plundering Paradise: The Struggle for the Environment in the Philippines. Berkeley: University of California Press.

Brosius Peter J. 2003. "Voices for the Borneo Rain Forest: Writing the History of the Environmental Campaign”. En Nature in the Global South. Environmental Projects in South and Southeast Asia, editado por Paul Greenough y Anna Lowenhaupt Tsing, 319-346. Durham: Duke University Press.

Brosius, J. Peter, Anna Tsing y Charles Zerner. 1998. "Representing Communities: Histories and Politics of Community-Based Natural Resource 
Management”. Society and Natural Resources 11: 157-168.

Bryant, Raymond L. y Sinead Bailey. 1997. Third World Political Ecology. Londres: Routledge.

Chayanov, A. V. 1966. On the Theory of the Peasant Economy, editado por Daniel Thorner, Baslie Kerblay y R. F. E. Smith. Homewood, III: R.D. Irwin.

Christie, Jan Wisseman. 1991. "States without Cities: Demographic Trends in Early Java”. Indonesia 52: 23-40.

Clifford, James y George Macus, eds. 1986. Writing Culture: The Poetics and Politics of Ethnography. Berkeley y Los Ángeles, California: University of California Press.

Corry, Stephen. 1993. "The Rainforest Harvest: Who Reaps the Benefit?”. Ecologist 23 (4): 148-53.

Coward, Walter 2005. "Building Models of Community-Based Natural Resource Management: A Personal Narrative”. En Communities and Conservation: Histories and Politics of Community. Based Natural Resource Management, editado por J. Peter Brosius, Ana Tsing, y Charles Zerner, 91-104. Walnut Creek, CA: AltaMira Press.

Cronon, William. 1983. Changes in the Land: Indians, Colonist, and the Ecology of New England. Nueva York: Hill and Wang.

Dalton, George. 1972. "Peasantries in Anthropology and History”. Current Anthropology 13 (4): 385-415.

Day, Tony. 1994. "'Landscape' in Early Java”. En Recovering the Orient: Artist, Scholars, Appropriations, editado por Andrew Gerstle y Anthony Milner, 175-203. Singapore: Harwood Academic Publishers.

Dewald, Jonathan y Liana Vardi. 1998. “The Peasantries of France: 1400-1789". En The Peasantries of Europe from the
Fourteenth to the Eighteenth Centuries, editado por Tom Scott, 21-47. Londres: Longman.

Dove, Michael. 1985. Swidden Agriculture in Indonesia: Subsistence Strategies of the Kalimantan Kantu. Nueva York: Mouton.

—. 1992. "Foresters'. Beliefs about Farmers as a Priority for Social Science Research in Social Forestry". Agroforestry Systems 17: 13-41.

Ellen, Roy F. 1986. "What Black Elk Left Unsaid: On the Illusory Images of Green Primitivism”. Anthropology Today 2 (6): 8-12.

Elson, R. E. 1994. Village Java under the Cultivation System, 1830-1970. Sídney: Allen and Unwin.

Espiritu, Socorro C. y Chester L. Hunt. 1964. Social Foundations of Community Development: Readings of the Philippines. Manila: R. M. Garcia.

Estrella, Conrado. 1969. The Democratic Answer to the Philippine Agrarian Problem. Manila: Solidaridad.

Farr, Ian. 1986. “'Tradition' and the Peasantry: On the Modern Historiography of Rural Germany”. En the German Peasantry, editado por Richard Evans y W. R. Lee, 1-36. Londres: Croom Helm.

Geertz, Clifford. 1963. Agricultural Involution: The Processes of Ecological Change in Indonesia. Berkeley: University of California Press.

Gouda, Frances. 1995. Poverty and Political Culture: The Rhetoric of Social Welfare in the Netherlands and France, 1815-1854. Landham, Md: Rowman and Littlefield.

Gramsci, Antonio. 1968. The Modern Prince and Other Writings. 3. ${ }^{\mathrm{a}}$ ed. Nueva York: International Publishers.

Guha, Ramachandra. 1990. The Unquiet Woods: Ecological Change and Peasant 
Resistance in the Himalaya. Berkeley y Los Ángeles: University of California Press.

—.1994. Social Ecology. Delhi: Oxford University Press.

Harrisson, Tom. 1970. The Malays of SouthWest Sarawak before Malaysia: A Socioeconomic Survey. East Lansing: Michigan State University Press.

Hart, Gillian. 1986. Power, Labor, and Livelihood: Precesses of Change in Rural Java. Berkeley: University of California Press.

—. 1991. "Engendering Everyday Resistance: Gender, Politics, Patronage, and Production in Rural Malaysia”. Journal of Peasant Studies 19 (1): 93-121.

—. 1992. "Household Production Reconsidered: Gender, Labor Conflict, and Technogical Change in Malaysian's Muda Region”. World Development 20 (6): 809-824.

Hart Gillian, Andrew Turton y Benjamin White, eds. 1989. Agrarian Transformations: Local Processes and the State in Southeast Asia. Berkeley: University of California Press.

Hawes, Gary. 1987. The Philippine State and the Marcos Regime: The Politics of Export. Ithaca: Cornell University Press.

Hirsh, Philip y Carol Warren, eds. 1998. The Politics of Environment in Southeast Asia. Londres: Routledge.

Hobsbawm, Eric J. 1973. "Peasants and Politics”. Journal of Peasants Studies 1 (1): 3-22.

Isaacman, Allen F. 1993. "Peasants and Rural Social Protest in Africa”. En Confronting Historical Paradigms, editado por Fred Cooper, 205-317. Madison: University of Wisconsin.

Kahn, Joel S. 1980. Minangkabau Social Formations: Indonesian Peasants and the
World Economy. Cambridge: Cambridge University Press.

Kartodirdjo, Sartono. 1973. Protest Movements in Rural Java: A Study of Agrarian Unrest in the Nineteenth and Early Twentieth Centuries. Singapore: Oxford University Press.

Kearney, Michael. 1996. Reconceptualizing the Peasantry: Anthropology in Global Perspective. Boulder: Westview.

Kemp, Jeremy. 1988. Seductive Mirror: The Search for the Village Community in Southeast Asia. Dodrect: Foris.

Kerkvliet, Benedict J. Tria. 1990. Everyday Politics in the Philippines: Class and Status in Relations in a Central Luzon Village. Berkeley: University of California Press.

Langton, John. 1998. "Conclusion: The Historical Geography of European Peasantries, 1400-1800”. En The Peasantries of Europe from the Fourteenth to the Eighteenth Centuries, editado por Tom Scott, 372-400. Londres: Longman.

Lehning, James R. 1995. Peasant and French: Cultural Contact in Rural France during the Nineteenth Century. Cambridge: Cambridge University Press.

Li, Tania. 1999. Transforming the Indonesian Uplands. Londres: Hardwood Academic Press.

-. 2000. "Articulating Indigenous Identity in Indonesia: Resource Politics and the Tribal Slot”. Comparatives Studies in Society and History 42 (1): 149-178.

Lim, Teck Ghee. 1977. Peasants and their Agricultural Economy in Colonial Malaya, 1874-1941. Kuala Lumpur: Oxford University Press.

Marx, Karl. 1972. The Eighteenth Brumaire of Luis Bonaparte. Nueva York: International Publishers. 
Mayer, Judith. 1996. "Environmental Organizing in Indonesia: The Search for a New Order". En Global Civil Society and Global Environmental Governance, editado por Ronnie Lipshutz, 167-213. Albany: State University of New York Press.

Monk, Paul, M. 1996. Truth and Power: Robert S. Hardie and Land Reform Debates in the Philippines, 1950-1987. Nueva York: Cambridge University Press.

Muijzenberg, Otto van den y Willem Wolters. 1988. Conceptualizing Development: The Historical-Sociological Tradition in Dutch Non-Western Sociology. Dordrecht: Foris.

Olson, Gary L. 1974. U.S Foreign Policy and the Third World Peasant: Land Reform in the Asia and Latin America. Nueva York: Praeger.

Ong, Aihwa. 1987. Spirits of Resistance and Capitalist Discipline: Factory Women in Malaysia. Albany: State University of New York Press.

-. 1990. "State versus Islam: Malay Families, Women's Bodies, and the Body Politic in Malaysia”. American Ethnologist 17 (2): 258-277.

Peet, Richard y Michael Watts. 1996. Liberation Ecologies: Environment, Development, Social Movements. Londres: Routledge.

Peluso, Nancy Lee. 2003. “Territorializing Local Struggles for Resource Control: A Look at Environmental Discourses and Politics in Indonesia”. En Nature in the Global South. Environmental Projects in South and Southeast Asia, editado por Paul Greenough y Anna Lowenhaupt Tsing, 231-252. Durham: Duke University Press.

-. 1992. Rich Forests, Poor People. Berkeley: University of California Press.

-. 1993. "Coercing Conservation: The Politics of State Resource Control". En The
State and Social Power in Global Environmental Politics, editado por R. Lipschutz y K. Conca. Nueva York: Columbia University Press.

Pelzer, Karl. 1945. Pioneer Settlement in the Asiatic Tropics. Nueva York: American Geographical Society.

Pemberton, John. 1994. On the Subjet of "Java". Ithaca: Cornell University Press.

Popkin, Samuel. 1979. The Rational Peasant: The Political Economy of Rural Society in Vietnam. Berkeley: University of California Press.

Posey, Darrell. 1985. "Indigenous Management of Tropical Forest Ecosystems: The Case of the Kayapo Indians of the Brazilian Amazon”. Agroforestry Systems 3: 139-158.

Putzel, James. 1992. A Captive Land: The Politics of Agrarian Reform in the Philippines. Nueva York: Monthly Review Press.

Reynolds, Craig. s. f. "The State in Southeast Asian History: Its Representations and Rivals”. Inédito.

Roseberry, William. 1993. "Beyond the Agrarian Question in Latin America”. En Confronting Historical Paradigms, editado por Fred Cooper, 318-368. Madison: University of Wisconsin Press.

Rosener, Werner. 1994. The Peasantry of Europe. Traducido por Thomas Barker. Oxford: Blackwell.

Sahabat Alam Malaysia, ed. 1987. Forest Resources Crisis in the Third World. Malaysia: Natraj Publishers; Third World Network.

Sahlins, Peter. 1994. Forest Rites: The War of the Demoiselles in Nineteenth Century France. Cambridge: Harvard University Press.

Said, Edward. 1978. Orientalism. Londres: Routledge; Kegan Paul. 
Scott, James C. 1976. The Moral Economy of the Peasant. New Haven: Yale University Press.

-. 1977. "Protest and Profanation: Agrarian Revolt and the Little Tradition". Theory and Society 4 (1): 1-38; 4 (2): 211-246.

-.1985. Weapons of the Weak: Everyday Forms of Peasant Resistance. New Haven: Yale University Press.

-. 1998. Seeing Like a State: How Certain Schemes to Improve the Human Condition Have Failed. New Haven: Yale University Press.

\section{Scott, James y Benedict J. Tria Kerkvliet,} eds. 1986. Everyday Forms of Peasant Resistance in South-East Asia. Totowa, N. J.: Frank Cass.

Shamsul, A. B. 1986. From British to Bumiputera Rule: Local Politics and Rural Development in Peninsular Malaysia. Singapore: Institute of Southeast Asian Studies.

Shanin, Theodor. 1990. Defining Peasants. Oxford: Blackwell.

Shiva, Vandana. 1989. Staying Alive: Women, Ecology, and Development in India. Londres: Zed.

Silverman, Sydel. 1979. "The Peasant Concept in Anthropology”. Journal of Peasant Studies 7 (1): 49-69.

Stivens, Maila. 1983. "Sexual Politics in Rembau: Female Autonomy, Matriliny, and Agrarian Change in Negeri Sembilan, Malaysia”. Occasional Paper 5, University of Kent at Canterbury, Centre of South-East Asian Studies.

Stoler, Ann. 2009. "Development Historical Negatives: Race and the Disquieting Visions of a Colonial State”. En Along the Archival Grain: Colonial Cultures and the Affective States, 105-140. Princeton: Princeton University Press.

Svensson, Thommy. 1990. "Bureaucracies and Agrarian Change: A Southeast Asian
Case”. En Agrarian Society in History, editado por Mats Lundahl and Thommy Svensson, 282-317. Londres: Routledge.

Takahashi, Akira. 1972. "The Peasantization of Kasama Tenants”. Philippine Sociological Review 20 (1-2): 129-133.

Taylor, Jean. 1983. The Social World of Batavia: European and Eurasian in Dutch Asia. Madison: University of Wisconsin Press.

Taylor, Peter y Frederick Buttel. 1992. "How Do We Know We Have Global Environmental Problems? Science and the Globalization of Environmental Discourse”. Geoforum 23 (3): 495-16.

Thompson, E. P. 1975. Whigs and Hunters: The Origins of the Black Act. Nueva York: Pantheon.

Tsing, Anna L. 1993. In the Realm of the Diamond Queen: Marginality in an Outof-the-Way Place. Princeton: Princeton University Press.

-. 1999. "Becoming a Tribal Elder and other Green Development Fantasies”. En Transforming the Indonesian Uplands: Marginality, Power and Production, editado por Tania Murray Li, 159-202. Ámsterdam: Harwood Academic Publishers.

Vickers, Adrian. 1986. "History and Social Structure in Ancient Java: A Review Article”. Review of Indonesian and Malayan Affairs 20 (2): 156-185.

Vries, Jan de. 1974. The Dutch Rural Economy in the Golden Age, 1500-1700. New Haven: Yale University Press.

Wolf, Eric R. 1966. Peasants. Engelwood Cliffs, N. J.: Prentice-Hall.

Wong, Diana. 1987. Peasant in the Marking: Malaysia's Green Revolution. Singapore: Institute of Southeast Asian Studies.

Worster, Donald. 1994. Nature's Economy: A History of Ecological Ideas. 2. ${ }^{\mathrm{a}}$ ed. Nueva York: Cambridge University Press. 
Zanden, J. L. van. 1994. The Transformation of European Agriculture in the Nineteenth Century: The Case of the Netherlands. Ámsterdam: VU University Press.

Zerner, Charles. 1994. "Through a Green Lens: Constructing Customary Envi- ronmental Law and Community in Indonesia's Maluku Islands". Law and Society Review 28 (5): 1079-1122. Número especial del simposio "Law and the Definition of Individual and Collective Selves: Community and Identity in Sociolegal Studies." 